\author{
QUARTERLY TECHNICAL PROGRESS REPORT \\ FOR THE PERIOD \\ JANUARY 1 THROUGH MARCH 31, 1990
}

\author{
J. W. Vogh \\ R. P. Anderson
}

Work Performed Under Contract DE-AC22-8BPC88810

\author{
Prepared for the \\ U.S. Department of Energy \\ Pittsburgh Energy Technology Center \\ Pittsburgh, Pennsylvania
}

\begin{abstract}
DISCLAIMER
This report was preparted as an account of work bonsored by an agency of the United States Government. Neither the Uniled States. Govnrnment nor any agency thereof, nor any of their employees, makes any warranty, express or implied, or assumes any legal liability or responsibllity for the accuracy, cumpleteness, or usetulness of any information, apparatus, product, or process disclosed, or represents that its use would not infringe privately owned rights. Reference herein to any specific commercial product, process, or service by trade name, trademark, manufacturer, or otherwise; does not necessarily constitute or imply its endorsement, recommendation, or favoring by the United States Government or any agency thereot. The views and opinions of authors expressed herein do not riecessarily state or reflect those of the United states Government or any agency thereof.
\end{abstract}

IIT Research Institute

NATIONAL INSTITUTE FOR PETROLEUM AND ENERGY RESEARCH

P. 0 . Box 2128

Bartlesville, Oklahoma 74005

(918) $336-2400$ 


\section{DEVELOPMENT OF ANALYTICAL PROCEDURES FOR COPROCESSING}

\section{SUMMARY}

Maya crude residue and 111 inois No. 6 coal have been processed together over a range of reactant ratios to produce material for study of the product composition and of the coprocessing chemistry. The reaction conditions have been described in previous reporis.

Acid fractions have been derivatized to produce ${ }^{13} \mathrm{C}$ tagged products suitable for NMR analysis. The acids have been identified as phenols and other oxygen acids, nitrogen acids including carbazoles, and benzylic and sulfur acids. All of the acid fractions appear to be essentially monofunctional. Base fractions were analyzed by nonaqueous titration and were shown to consist of azaarenes and arylamines. Two of the distillates boiling. below $175^{\circ} \mathrm{C}$ were analyzed by PIANO capillary gas chromatography.

Maya crude petroleum fractions similar to those obtained from coprocessing products have been analyzed for carbon isotope ratios. These fractions were prepared directly from the Maya crude without application of hydrogenation or other processing chemistry. Trends indicating isotopic fracionation coprocessing to that reported earlier for coprocessing products were observed.

\section{INTRODUCTION}

Coprocessing of petroleum residue and coal has been developed as a useful method for conversion of these low value materials to higher value liquid products. The conversion of petroleum residue is often improved in the coprocessing procedures and in addition the coal provides a low cost addition to the liquid products. In this project the reactants examined are Maya crude residue, bp $>1000^{\circ} \mathrm{F}$, and Illinois No. 6 coa 1 .

An objective of this study is the development of an understanding of the contributions of the residue and coal separately to the final products. This has been approached through detailed separation and identification of the products and carbon issitope ratio determinations of all significant fractions. Knowledge of the product composition and the source of the components from residue and coal can aid in improvement of reaction conditions and selection of reactants. In addition, it can provide a better understanding of the reaction chemistry underlying the coprocessing procedures. 
The initial part of this project was preparation of a series of products from a variety of residue and coal mixtures for further study. The amount of coal in the reaction mixtures ranged from 2 to 40 weight percent. Details on the reaction conditions and preliminary workup have been provided in previous reports. The products have been further separated into specific chemical classes in discrete boiling ranges. Detailed composition results have been reported on many of these fractions and some results on selectivity in production of specific chemical classes have also been produced.

Carbon isotope ratio analys is is a potentially effective method for determining the origin of a component or compound class. The residue and coal used in this study have a difference of $3.00 \cdot 8^{13} \mathrm{C}$ units. If the products can be shown to have a linear relationship in isotope ratios to the reactant composition, this analysis can be important in determining the origin of the coprocessing products.

This report presents several aspects of the detailed analysis of some of the polar and neutral fractions.

\section{EXPERIMENTAL}

\section{Derivatization of Acids}

A procedure hils been developed for the specific alkylation of acidic functional groups present in petroleum and related products. Samples (weighed to provide about 0.2 gram of product) were combined with about 2 equivalents of potassium hydroxide in about $4 \mathrm{~mL} 1$-methy 1-2-pyrrolidinone. To this, about 20 percent excess of iodomethane was added. After mixing, it was held at $45^{\circ} \mathrm{C}$ for one hour. It was then poured into water and extracted with ethyl ether to obtain the product. This method provided a standard procedure for $N$ and 0 methylation of a wide variety of acidic compounas. Nearly quantitative conversion was obtained for compounds such as indole, carbazole, phenols, (including 2-naphthol and 2,6-di-tert-butyl-4-methylphenol), thiols and aromatic amides. Also, compounds with benzyitic hydrogen activated by neighboring groups, such as fluorene, and oxindole, were completely converted to the methylated form. 


\section{NMR Analysis of Derivatized Acids}

This methylation procedure using ${ }^{13} \mathrm{C}$ enriched iodomethane $\left(99 \%+{ }^{13} \mathrm{CH}_{3} \mathrm{I}\right)$ was applied to the 175-350 and 350-538" C acid fractions of the coprocessing products. Samples of the acid fractions were also reacted using normal iodomethane $\left(1.1 \%{ }^{13} \mathrm{CH}_{3} \mathrm{I}, 98.9 \%{ }^{12} \mathrm{CH}_{3} \mathrm{I}\right)$. Each sample was dissolved in deuterochloroform ( $\mathrm{CDCl}_{3} ; 99.6 \%$. D) using tetramethylsilane (TMS) as the internal chemical shift reference. Four types of NMR experiments were run on each of the ${ }^{13} \mathrm{CH}_{3}$ derivatized samples using a JEOL GX-270 FT-NMR spectrometer operating at $270.15 \mathrm{MHz}$ for ${ }^{1} \mathrm{H}$ and $67.94 \mathrm{MHz}$ for ${ }^{13} \mathrm{C}$; a proton NMR experiment (45" pulse, 5 s'ec. pulse delay, 64 pulse summation); a quantitative ${ }^{13} \mathrm{C}$ NMR experiment (gated-decoupling of protons during signal acquisition, $30^{\circ}$ pulse, $20 \mathrm{sec}$ pulse delay, 3200 pulse summation); a DEPTD experiment (Distortioniess Enhancement by Polarization Transfer with proton Decoupling) to differentiate the methyl carbon signals $\left(135^{\circ}\right.$ pulse $(\theta), 5 \mathrm{sec}$ pulse delay, 600 pulse summation); a CHSHF (Carbon Hydrogen SHiFt correlation; cuneriment correlating the ${ }^{1} \mathrm{H}$ chemical shift with the ${ }^{13} \mathrm{C}$ chemical shift ${ }^{1} \mathrm{H}: 1500 \mathrm{~Hz}, 128$ points; ${ }^{13} \mathrm{C}$ : $4800 \mathrm{~Hz}, 1024$ points; 192 pulse summation eàch ${ }^{1} \mathrm{H}$ point, $1.893 \mathrm{sec}$ pulse delay). The first three experiments were also run on each of the ${ }^{12} \mathrm{CH}_{3}$ derivatized samples.

\section{Base Titration}

The base fractions isolated from all of the $175-350$ and $350-538^{\circ} \mathrm{C}$ distillates have been analyzed by nonaqueous titration. Samples of each base fraction were titrated in both acetonitrile and acetic anhydride with $0.01 \mathrm{~N}$ perchloric acid in dioxane as the titrant. The titrations were monitored by a glass electrode and a $\mathrm{Ag} / \mathrm{AgCl}$ electrode that was modified for this procedure.

\section{High Resolution Gas Chromatographic Analys is of Light Hydrocarbons}

The distillates boiling below $175^{\circ} \mathrm{C}$ obtained from the 2 and 40 percent coal coprocessing reactions have been analyzed by the PIANO method. This is a capillary gas chromatographic method developed for light hydrocarbon analysis and provides detailed reporting for the hydrocarbon classes of paraffins, isoparaffins, aromatics, naphthenes, and olefins. The reporting procedure is based on a large library of retention times of identified hydrocarbons and produces a report showing detailed composition of the sample as well as sumirary by class and carbon numbers. 


\section{Carbon Isotope Ratios}

Carbon isotope ratio analysis on samples of. Maya crude oil fractions were carried out by Dr. Michael Engle at the School of Geology and Geophysics, Energy Center, University of Oklahoma, Norman, Oklahoma.

\section{RESULTS AND DISCUSSION}

\section{Acids Analys is}

Table 1 shows the ${ }^{1} \mathrm{H}$ and ${ }^{1} \mathrm{C}$ chemical shifts of the ${ }^{13} \mathrm{CH}_{3}$ group for nine model compounds methylated using ${ }^{13} \mathrm{C}$ enriched iodomethane together with the methylation yield based on ${ }^{13} \mathrm{C}$ peak integrals. The uncertainty in the yields is about $+7 \%$. Several of the metnylated compounds conlain methyl peaks from side products apparently formed during methylation. These have been identified where possible. These were chosen because they represent possible functional structures present in petroleum acidic classes.

Table 1

Proton $\left({ }^{1} \mathrm{H}\right)$ and Carbon-13 $\left({ }^{13} \mathrm{C}\right)$ Chem cal Shifts of Methylated Model Compounds

\begin{tabular}{|c|c|c|c|}
\hline Compound & $\delta\left({ }^{13} \mathrm{C}\right)^{\mathrm{d}}, \mathrm{ppm}$ & $\delta\left({ }^{\prime} H\right)^{\alpha}, p p m$ & $\begin{array}{l}\text { hylation } \\
\text { ield, \% }\end{array}$ \\
\hline Methyl tolyl sulfide & $\begin{array}{l}16.5 \\
43.5(4 \%)\end{array}$ & $\begin{array}{l}2.40 \\
2.63 \text { (DMSO Imp.) }\end{array}$ & 95 \\
\hline 9-Hydroxyfluorene (9-methyl) & 26.5 & $1.67\left(-\mathrm{CCH}_{3}\right)$ & 95 \\
\hline Fluorene $(9,9$-dimethy 1$)$ & $\begin{array}{l}51.5 \\
27.0 \\
18.0(6.5 \%)\end{array}$ & $\begin{array}{l}2.73\left(-\mathrm{OCH}_{3}\right) \\
1.46 \\
1.48 \text { (Imp.) }\end{array}$ & 84 \\
\hline $\mathrm{N}$-methylcarbazole & 28.5 & 3.75 & 96 \\
\hline $\mathrm{N}$-methylindole & 32.5 & 3.48 & 96 \\
\hline $\mathrm{N}$-methyl-N-phenylvaleramide & 37.5 & 3.22 & 95 \\
\hline $\begin{aligned} N \text {-methylindazole }(1-N) \\
(2-N)\end{aligned}$ & $\begin{array}{l}35.0(80 \%) \\
39.7(20 \%)\end{array}$ & $\begin{array}{l}3.95 \\
4.05 \text { (rearrangement) }\end{array}$ & 100 \\
\hline $\begin{array}{l}\text { Myristic acid (methyl ester) } \\
\text { 2-Naphthyl methyl ester }\end{array}$ & $\begin{array}{l}51.5 \\
55.2\end{array}$ & $\begin{array}{l}3.62 \\
3.85\end{array}$ & $\begin{array}{l}90 \\
96\end{array}$ \\
\hline
\end{tabular}

${ }^{\mathrm{a}}$ Chemical shifts referenced to internal TMS, $\delta($ TMS $)=0.00$ 
Table 2 shows the estimated mean equivalent molecular weights (EW) obtained for the coprocessing sample acid fractions using nonaqueous titration. Assuming an average carbon:hydrogen ratio of $1: 1.5$ for these acid fraclions, the estimated number of carbons per average molecule was calculated assuming that the compounds are monofunctional in oxygen or nitrogen content. These average carbon numbers are also shown in Table 2 for each acid fraction.

Table 2

Acid Fraction Equivalent Weights and Carbon Number

\begin{tabular}{lrrrr}
\hline Coal, percent & 2 & 20 & 30 & 40 \\
\hline $175-350^{\circ} \mathrm{C}$ & 184 & 173 & 167 & 158 \\
EW & 12.5 & 11.7 & 11.3 & 10.6 \\
Carbon No. & & & & \\
$350-538^{\circ} \mathrm{C}$ & 292 & 250 & 248 & 259 \\
EW & 20.5 & 17.4 & 17.3 & 18.1 \\
Carbon No. & & & &
\end{tabular}

The carbon number will be used later to calculate the average number of functional groups per molecule for the acid fractions.

Figures 1-8 show the CHSHF two-dimensional contour plots of the acid fractions. In these figures the individual peaks are shown as closed contours of signal height (intensity) plotted at the coordinates of the ${ }^{13} \mathrm{C} /{ }^{1} \mathrm{H}$ chemical shifts referenced to the TMS signal in the upper right corner. The ${ }^{13} \mathrm{C}$ chemical shift is the horizontal axis, and the 'H chemical shift is the vertical axis. Also shown in each figure are horizontal and vertical projections of the peak intensity which represent the proton and carbon-13 spectra, respectively, plotted as chemical shift relative to the TMS peak used as internal chemical shift reference. In figure 1, the three regions of interest for methylated oxygen, nitrogen and benzylic/suifur furctional groups present in the acid subfractions are labeled. Based in part on results for pure compounds in Table 1, the oxygen region was defined as the region from 49-65 ppm $\left({ }^{13} \mathrm{C}\right)$ and $2.7-4.2 \mathrm{ppm}\left({ }^{1} \mathrm{H}\right)$. Similarly, the nitrogen region was found to extend from $28-49 \mathrm{ppm}\left({ }^{13} \mathrm{C}\right)$ and $3.0-4.4 \mathrm{ppm}\left({ }^{1} \mathrm{H}\right)$. The benzylic/sulfur region extends from $5-28 \mathrm{ppm}\left({ }^{13} \mathrm{C}\right)$ and $1.4-3.0 \mathrm{ppm}\left({ }^{1} \mathrm{H}\right)$. 
Above the benzylic/sulfur region is the region from $10-38 \mathrm{ppm}\left({ }^{13} \mathrm{C}\right)$ and $0.5-$ 1.4 ppm ('H) which contains peaks typical of alkyl carbons. "The peaks of alkyl carbons alpha to aromatic structures can have ' $H$ shifts up to $3.0 \mathrm{ppm}$; so peaks from these components could interfere with benzylic/sulfur assignments. These same regions apply to the other figures 2-8.

The oxygen region nay be further subdivided into three subregions based on the ${ }^{13} \mathrm{C}$ chemical shift. The methyl esters of carboxylic acids $\left(-\mathrm{COOCH}_{3}\right)$ have ${ }^{13} \mathrm{C}$ shifts from $49-54 \mathrm{ppm}$ with the primary position being $51-52 \mathrm{ppm}\left({ }^{1} \mathrm{H}\right.$ chemical shifts are typicaliy 3.6-4.0 ppm). The methylated phenols or hydroxyl groups $\left(-\mathrm{OCH}_{3}\right)$ have ${ }^{13} \mathrm{C}$ shifts from $54-59 \mathrm{ppm}\left({ }^{1} \mathrm{H}\right.$ shifts are typically 3.5-4.2 ppm for aromatic methoxy groups and 3.2-3.5 ppm for aliphatic methoxy groups). However, hindered phenolic groups $\left(-\mathrm{OCH}_{3}(\mathrm{H})\right)$ which have two ortho-substituents exhibit ${ }^{13} \mathrm{C}$ shifts from 59-63 ppm ( $\mathrm{H}$ shifts are similar to those of other methoxy groups). These three subregions seem to be we 11-defined with essentially no overlap based on the ${ }^{13} \mathrm{C}$ chemical shifts of many compounds. However, the methylated model compound 9-hydroxyfluorene had a ${ }^{13} \mathrm{C}$ shift for the $-\mathrm{OCH}_{3}$ group of $51.5 \mathrm{ppm}$ with a ${ }^{1} \mathrm{H}$ shift of $2.75 \mathrm{ppm}$, both outside the typical ranges for the $-\mathrm{OCH}_{3}$ groups. A series of $9-n$-alkylfluorene-9-0ls has previously been identified in petroleum, but may not be present in these coprocessing samples.

Within the nitrogen region those methyls attached to amine type nitrogens have 'H shifts around 3.0-3.2 ppm while methyls attached to nitrogen in aromatic rings or condensed ring systems have 'H shifts from 3.4-4.4 ppm. For example, the methylated model compound carbazole has a ${ }^{13} \mathrm{CH}_{3}$ shift of $28.5 \mathrm{ppm}$ $\left({ }^{13} \mathrm{C}\right)$ and $3.75 \mathrm{ppm}\left({ }^{1} \mathrm{H}\right)$. If the ring system has several nearby nitrogens, the 'H shift of the $\mathrm{N}$-methyls is generally toward the higher end of the range.

Within the benzylic/sulfur region, methyl sulfides generally have 'H shifts from 2.0-2.5 ppm with aromatic methyl sulfides around 2.4-2.5 ppm. The ${ }^{13} \mathrm{C}$ shifts of methyl sulfides are generally from 10-20 ppm. Benzylic methyls have 'H shifts typically from 1.4-2.0 ppm.

Figure 1 shows that the 2 percent coal, 175-350 $\mathrm{C}$ acid fraction contains substantial oxygen and nitrogen methylated classes with some peaks in the benzylic/sulfur region. Within the oxygen region the most prominent peak is that typical of methylated phenolic groups at $55.0 \mathrm{ppm} / 3.70 \mathrm{ppm}\left({ }^{13} \mathrm{C} /{ }^{1} \mathrm{H}\right)$, with a smaller group of peaks typical of hindered methylated phenols at $60 \mathrm{ppm} / 3.65$ 
ppm, with several smaller peaks from other methylated oxygen classes of intermediate nature.

There is a substantial group of methylated nitrogen classes with carbazole prominent as the peak at the right edge of this region at $28.7 \mathrm{ppm} / 3.71 \mathrm{ppm}$. $\mathrm{N}$-methyl indole would appear to be outside this group based on the 'H shift of $3.48 \mathrm{ppm}$, but $\mathrm{N}$-methylindazole would appear to be a good representative at $35.0 \mathrm{ppm} / 3.95 \mathrm{ppm}$ (39.7 ppm/4.05 ppm for the rearrangement product). $\mathrm{N}$-methy $1-\mathrm{N}$-phenylvaleramide also appears to be an unlikely candidate based on the ${ }^{1} \mathrm{H}$ shift of $3.22 \mathrm{ppm}$ for the methyl protons. The group of peaks at 44 ppm/2.9 ppm is atypical but might be an amine derivative.

The two groups of peaks in the benzylic/sulfur region at $15.5 \mathrm{ppm} / 2.35 \mathrm{ppm}$ and $19.0 \mathrm{ppm} / 2.2 \mathrm{ppm}$ have ${ }^{13} \mathrm{C}$ and ${ }^{1} \mathrm{H}$ shifts that are representative of methylated sulfur functional groups. This is the only sample that shows the probable presence of sulfur functional groups; the others have some peaks in this region more typical of benzylic derivatives.

For the rest of the $175-350^{\circ}$ C acid fraction CHSHF spectra in Figures 2-4, the trends are the increasing prominence of the methylated phenolic group peak at $55 \mathrm{ppm} / 3.7 \mathrm{ppm}$ and the decreasing presence of methylated nitrogen or benzylic/sulfur peaks. Figure 2 contains two strange broad low intensity signals at $42 \mathrm{ppm} / 3.7 \mathrm{ppm}$ and at $55 \mathrm{ppm} / 4.3 \mathrm{ppm}$. The appearance of these peaks is not characteristic of peaks displayed in CHSHF spectra and they are probably artifacts of some type. A common artifact of the CHSHF experiment are the "tails" extending vertically in the "H shift direction for prominent peaks when low contours are used to show weaker peaks. These artifacts are evident in Figure 1 and strongly in Figures 2-4 for the phenolic derivative peaks.

Comparing the 350-538" C acid fraction CHSHF spectra shown in Figures 5-8 with the lower temperature spectra reveals that nitrogen functional groups are much more prominent in these higher temperature fractions. The carbazole derivative peak at $28.7 \mathrm{ppm} / 3.6 \mathrm{ppm}$ is prominent in a 11 the Figures $5-8$. The phenolic derivative peak at $55 \mathrm{ppm} / 3.7 \mathrm{ppm}$ is present in Figure 5 and increases strongly in intensity in Figures 6-8. This peak also appears to have several overlapping components while the corresponding peak in the lower temperature fractions was indicative of mostiy one component. There is no evidence of sulfur derivatives in these fractions and possible benzylic derivatives are most prominent in Figure 6 for the 20 percent coal acids. 
The CHSHF experiment is inherentily not quantitative; so the intensities or integrals of peaks in Figures 1-8 cannot be used as a measure of the exact proportions of each actd class present in each sample. Thus the following treatment is used to obtain quantitative results. Tables 3-7 show the functional class integrals, the intermediate values used in determination of relative abundance of the classes, and finalily the number of functional groups per average molecule. In Table 3 are shown the ${ }^{13} \mathrm{C}$ peak integrals from the quantitative ${ }^{13} \mathrm{C}$ NMR experiments for both the ${ }^{13} \mathrm{CH}_{3}$ and ${ }^{12} \mathrm{CH}_{3}$ methylated samples of each fraction. The integrals are shown for four regions: the aromatic region (110-160 ppm) and the oxygen, nitrogen, and benzylic/sulfur regions previously identified. The aromatic carbon structure has been assumed to be unaltered by the methylation process; so all integrals have been scaled to give the same result for the aromatic region.

Table 3

Quantitative Carbon-13 NMR Peak Integrals

\begin{tabular}{|c|c|c|c|c|c|}
\hline Sample, \% Coal & $\begin{array}{l}\text { Arom. } \\
110-160 \mathrm{ppm}\end{array}$ & $\begin{array}{c}0 \\
49-65 \mathrm{ppm}\end{array}$ & $\stackrel{N}{28-49} \mathrm{ppm}$ & $\begin{array}{c}\mathrm{B} / \mathrm{S} \\
5-28 \mathrm{ppm}\end{array}$ & Total \\
\hline 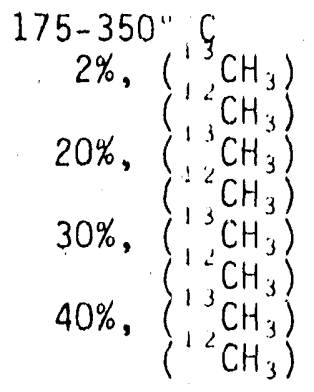 & $\begin{array}{l}82.08 \star \\
82.08 \\
82.08 \\
82.08 \\
82.08 \\
82.08 \\
82.08 \\
82.08\end{array}$ & $\begin{array}{r}520.27 \\
5.57 \\
1048.78 \\
8.35 \\
1015.19 \\
10.69 \\
1122.85 \\
11.63\end{array}$ & $\begin{array}{r}312.32 \\
15.42 \\
178.89 \\
19.07 \\
57.84 \\
18.18 \\
69.57 \\
17.68\end{array}$ & $\begin{array}{r}108.14 \\
30.11 \\
45.01 \\
27.03 \\
29.91 \\
25.91 \\
39.92 \\
25.13\end{array}$ & $\begin{array}{r}1022.81 \\
133.18 \\
1354.76 \\
136.53 \\
1185.74 \\
136.86 \\
1314.42 \\
136.52\end{array}$ \\
\hline 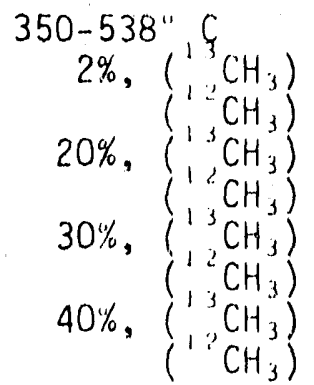 & $\begin{array}{l}82.08 \\
82.08 \\
82.08 \\
82.08 \\
82.08 \\
82.08 \\
82.08 \\
82.08\end{array}$ & $\begin{array}{r}103.69 \\
0.82 \\
322.41 \\
7.14 \\
360.18 \\
3.11 \\
439.72 \\
3.14\end{array}$ & $\begin{array}{r}405.51 \\
16.82 \\
261.61 \\
21.26 \\
209.09 \\
15.88 \\
238.98 \\
14.84\end{array}$ & $\begin{array}{l}48.33 \\
21.00 \\
76.96 \\
16.90 \\
42.45 \\
17.73 \\
62.59 \\
15.33\end{array}$ & $\begin{array}{l}639.61 \\
120.5 \\
743.06 \\
127.38 \\
693.80 \\
118.80 \\
823.37 \\
115.39\end{array}$ \\
\hline
\end{tabular}

*The integrals for each sample were scaled to make the aromatic integral the same. The aromatic region was assumed to be invariant during methylation. 
Table 4 shows the relative proportions of the three oxygen subclasses present in each acid fraction for each temperature cut. As discussed prevfously, from a qualitative aspect in figures 1-8 and confirmed here quantitatively, phenols are the most prominent oxygen functional group, particularly in the lower temperature fractions. The higher temperature fractions have higher contributions from hindered phenols and carboxylic acids. The higher coal contents result in more phenolic groups in both temperature ranges.

Table 4

Quantitative Subdivision of Oxygen Functionalities

\begin{tabular}{lrrrr}
\hline Coal, percent & 2 & 20 & 30 & 40 \\
\hline $175-350^{\prime \prime} \mathrm{C}$ & & & & \\
$-\mathrm{COOCH}_{3}$ & 5.1 & 1.5 & 0.4 & 0.5 \\
$-\mathrm{CCH}_{3}$ (hind.) & 75.2 & 90.2 & 97.1 & 94.8 \\
$-\mathrm{CCH}_{3}$ (hind & 19.7 & 8.3 & 2.5 & 4.7 \\
$350-538{ }^{\prime \prime}$ & & & & \\
$-\mathrm{COOCH}_{3}$ & 9.1 & 3.9 & 0.8 & 1.3 \\
$-\mathrm{OCH}_{3}$ (hind.) & 57.3 & 82.3 & 87.5 & 86.6 \\
$-\mathrm{OCH}_{3}$ (hind.) & 33.6 & 13.8 & 11.7 & 12.1 \\
\hline
\end{tabular}

The integral values of Table 3 provide the information required to. determine the amounts of the acid functional groups present in the samples. In combination with the titration values shown in Table 2 , the number of functional groups of each acid type for the average molecule can be determined as well as the totai number of acid groups. Table 5 contains intermediate values required in calculation of the number of functional groups. The values ${ }^{13} \mathrm{R}$ and ${ }^{12} \mathrm{R}$ represent the sum of integrals over a $11{ }^{13} \mathrm{C}$ response areas and are obtained from the last columns of each distlllate section of Table 3 . These $R$ values may be represented by equations 1 and 2 as the sum of functional and non-functional ${ }^{13} \mathrm{C}$.
1) $0.011 \mathrm{~N}_{C} I+0.011 \mathrm{~N}_{d} I={ }^{1} \mathrm{R} \quad\left({ }^{12} \mathrm{CH}_{3}\right.$ derivative $)$
2) $0.011 \mathrm{~N}_{\mathrm{C}} I+0.99 \mathrm{~N}_{\mathrm{d}} \mathrm{I}={ }^{13} \mathrm{R} \quad\left({ }^{13} \mathrm{CH}_{3}\right.$ derivative $)$ 
Table 5

Intermedtate Values (see text)

\begin{tabular}{|c|c|c|c|c|}
\hline Coal, percent & 2 & 20 & 30 & 40 \\
\hline \multicolumn{5}{|l|}{$175-350^{\circ} \mathrm{C}$} \\
\hline${ }^{13} \mathrm{R}$ & 1022.81 & 1354.76 & 1185.74 & 1314.42 \\
\hline${ }^{12} \mathrm{R}$ & 133.18 & 136.53 & 136.86 & 136.52 \\
\hline$x$ & 12.52 & 11.70 & 11.26 & 10.59 \\
\hline $\mathrm{N}_{\mathrm{C}} \mathrm{I}$ & 11198.6 & 11167.5 & 11370.4 & 11207.7 \\
\hline$N_{d} I$ & 908.7 & 1244.4 & 1071.4 & 1203.2 \\
\hline$N_{d} / N_{c}\left(\star 10^{4}\right)$ & 811.4 & 1114.3 & 942.3 & 1073.5 \\
\hline$X \star N_{d} / N_{C}$ & 1.016 & 1.304 & 1.061 & 1.137 \\
\hline \multicolumn{5}{|l|}{$350-538^{\circ} \mathrm{C}$} \\
\hline${ }^{13} \mathrm{R}$ & 639.61 & 743.06 & 693.80 & 823.37 \\
\hline${ }^{12} R$ & 120.58 & 127.38 & 118.80 & 115.39 \\
\hline$x$ & 20.52 & 17.41 & 17.26 & 18.07 \\
\hline$N_{C}{ }^{i}$ & 10431.7 & 10951.1 & 10212.7 & 9766.8 \\
\hline$N_{d} I$ & 530.2 & 628.9 & 587.3 & 723.2 \\
\hline$N_{d} / N_{c}\left(* 10^{11}\right)$ & 508.2 & 574.3 & 575.1 & 740.4 \\
\hline$x \star N_{d} / N_{c}$ & 1.043 & 1.000 & 0.993 & 1.338 \\
\hline
\end{tabular}

In these equations $N_{C}$ and $N_{d}$ represent the quantity of ${ }^{13} \mathrm{C}$ contained in the sample in the coprocessing acid fraction and in the derivatizing methyl groups, respectively. The coefficients 0.011 and 0.99 are the natural abundance of ${ }^{13} \mathrm{C}$ and the enriched content of ${ }^{13} \mathrm{CH}_{3} \mathrm{I}$. I is a scaling constarit of undetermined value relating the quantity of ${ }^{13} \mathrm{C}$ to its NMR integral response. Equations 1 and 2 may be rearranged to determine the values of $N_{C} I$ and $\mathrm{N}_{\mathrm{d}} \mathrm{I}$ :
3) $N_{C} l=\left({ }^{12} R+0.01124\left({ }^{12} R-{ }^{3} R\right)\right) / 0.011$
4) $N_{d} I=\left({ }^{13} R-{ }^{12} R\right) / 0.979$ 
The values of $N_{d} / N_{C}$ in Table 5 are determined from $\left(N_{d} I\right) /\left(N_{c} I\right)$. Determination of the average number of carbon atoms per molecule are based on the assumption that the typical acid is monofunctional with a mean formula of $\left(C_{X} H_{1} .5 x Y\right)$. Y represents etther nttrogen or oxygen and is taken to have atomic weight of 15 . The values of $X$ representing the number of carbon atoms per molecule are determined from the equivalent weights of Table 2 by the relations:

$$
\text { 5) } x=(E W-15) / 13.5
$$

The last row in each distfllate section, $X N_{d} / N_{c}$, represents the est timate of the total number of functional groups per molecule for each of the actd fractions.

Table 6 shows the values for the net enhancement of ${ }^{13} \mathrm{C}$ integral response due to the derivatization procedure. The numbers shown are the difference between the ${ }^{13} \mathrm{CH}_{3}$ and the ${ }^{12} \mathrm{CH}_{3}$ integral values over each zone between 5 and $65 \mathrm{ppm}$ for each acid fraction. The sums of these values for each sample are shown in the last row of both distillate ranges. Ratios of individual enhancement values to the total of each set (the fractional values of enhancement) are multiplied by the total number of functional groups per molecule to obtain the number of specific functional groups per molecule shown in Table $\%$.

Table 6

Net Peak' Integral Values

\begin{tabular}{lrrrr}
\hline Coal, percent & 2 & 20 & 30 & \multicolumn{1}{c}{40} \\
\hline $175-350^{\circ} \mathrm{C}$ & & & & \\
$-0,49-65 \mathrm{ppm}$ & 514.70 & 1043.43 & 1005.22 & 1111.22 \\
$-\mathrm{N}, 28-49 \mathrm{ppm}$ & 296.90 & 159.82 & 39.66 & 51.89 \\
$-\mathrm{B} / \mathrm{S}, 5-28 \mathrm{ppm}$ & 78.03 & 17.98 & 4.00 & 14.79 \\
Total & 889.63 & 1218.23 & 1048.88 & 1177.90 \\
$350-538^{\circ} \mathrm{C}$ & & & & \\
$-0,49-65 \mathrm{ppm}$ & 102.87 & 315.27 & 357.07 & 436.58 \\
$-\mathrm{N}, 28-49 \mathrm{ppm}$ & 388.83 & 240.35 & 193.21 & 224.14 \\
$-B / S, 5-28 \mathrm{ppml}$ & 27.33 & 60.06 & 24.72 & 47.26 \\
Total & $\overline{519.03}$ & $\overline{615.68}$ & $\overline{575.00}$ & $\overline{707.98}$ \\
\hline
\end{tabular}


Table 7

Number of Functional Groups Per Average Molecule

\begin{tabular}{lllll}
\hline Coa1, percent & 2 & 20 & 30 & 40 \\
\hline $175-350^{\circ} \mathrm{C}$ & & & & \\
$-0,49-65 \mathrm{ppril}$ & 0.58 & 1.11 & 1.02 & 1.07 \\
$-\mathrm{N}, 28-49 \mathrm{ppm}$ & 0.34 & 0.17 & 0.04 & 0.05 \\
$-B / S, 5-28 \mathrm{ppm}$ & 0.09 & 0.02 & 0.00 & 0.01 \\
Tota1 & 1.02 & $\overline{1.30}$ & $\overline{1.06}$ & $\overline{1.14}$ \\
$350-538^{\prime \prime} \mathrm{C}$ & & & & \\
$-0,49-65 \mathrm{ppm}$ & 0.21 & 0.51 & 0.62 & 0.83 \\
$-N, 28-49 \mathrm{ppm}$ & 0.78 & 0.39 & 0.33 & 0.42 \\
$-B / S, 5-28 \mathrm{ppmi}$ & 0.06 & 0.10 & 0.04 & 0.09 \\
Total & $\overline{1.04}$ & $\overline{1.00}$ & $\overline{0.99}$ & $\overline{1.34}$ \\
\hline
\end{tabular}

Values for the total number of functional groups generally fall near 1.0 and it is probable that all of the coprocessing acids are essentially monofunctional. The 20 percent coa $1,175-350^{\circ} \mathrm{C}$ sample shows a value of 1.3 in this study. However, in the October-December 1989 quarterly report this sample was shown by GC/MS study to be almost entirely monofunctional in composition with only a small amount of bisphenols as difunctional content. Some errors in the NMR spectra integral values arising from baseline correction or in the nonaqueous titration maly account for values that are significantly different from 1.0 .

Figures 9 and 10 show graphically the number of functional groups of each type in the $175-350$ and $350-538^{\circ} \mathrm{C}$ fractions, respectively. Using the relative data of Table 4 for the distribution of oxygen classes within the three subdivisions and the results from Table 7 showing the number of oxygen functional groups per nolecule $(49-65 \mathrm{ppm})$, the number of oxygen functional groups per molecule of each of the three types was determined for each acid fraction. These results are shown in Figures 11 and 12 and illustrate the change in prominence of the three oxygen classes across the fractions.

The results shown in Table 7 and Figures 9 and 10 are somewhat erratic when examined to determine trends in composition with reactant composition. However, it is clear that the relative amounts of phenolic and nitrogen acid compounds are significantly different in the 2 percent coal products from the 
other coprocessing samples. Phenols dominate it the other samples while nitrogen acids are more significant in the $350-\$ 38^{\circ} \mathrm{C}$ samples than in the $175-$ $350^{\circ} \mathrm{C}$ distillates. Generally, nitrogen acids diminish with increasing coal reactant content. Figures 11 and 12 confirm the observations made previously that phenols are the dominant oxygen class in all cases.

\section{Base Fractions Analyses}

The base fractions isolated from all of the coprocessing distillates have been analyzed by, nonaqueous titration. The solvents used were acetonitrile and acetic anhydride and the titrations were monitored by special glass electrodes.

This procedure determines bases in strong and weak basic strength classes. Strong bases inciude azaarenes (e.g., pyridine, quinoline, etc.) and arylamines (e.g., aniline, etc.). Titration in $\mathrm{CH}_{3} \mathrm{CN}$ determines both of these together while titration in acetic anhydride detects azaarenes alone because arylamines are acetylated in this solvent. Weak bases determined by this procedure include sulfoxides, diarlyamines, amides, and carbonyl classes.

No weak bases were detected in any of the coprocessing base samples. This contrasts with the composition of petroleum fractions in which weak bases are often significant. It is possible that the coprocessing reaction converts these components to neutral or strong base materials. Table 8 shows the titration results for the samples. The content of the components in the base fractions is reported in terms of milliequivalents per gram of sample. The estimated mean molecular weight of each base fraction is shown. The values shown for the $175-350^{\circ} \mathrm{C}, 30$ percent coal fraction may indicate solvent residue in the sample. 
Table 8

Titration Analysis of Base Fractions

\begin{tabular}{lrrrr}
\hline Codl, percent & 2 & 20 & 30 & 40 \\
\hline $175-350^{\circ} \mathrm{C}$ & & & & \\
Azaarenes, meq/g & 3.79 & 3.39 & 1.95 & 2.86 \\
Arylamines, meq/g & 1.02 & 1.58 & 1.26 & 1.46 \\
Equivalent M.W. & 208 & 201 & 312 & 231 \\
350-538 C & & & & \\
Azaarenes, meq/g & 2.49 & 2.60 & 2.22 & 2.66 \\
Arylamines, meq/g & 0.36 & 0.50 & 0.48 & 0.53 \\
Equivalent M.W. & 351 & 323 & 370 & 313 \\
\hline
\end{tabular}

Table 9 shows the results converted to the whole distillate basis. For reference, the values for the amount of base in the distillates are included. The yields are shown in terms of milliequivalents per gram of distillate. Trends in content of both azaarenes and arylamines with coal content are similar to that of yields of base fractions described in previous quarterly reports. It appears that the levels of azaarenes increase and arylamines decrease in the higher boiling distillates.

Table 9

Base Class Composition of Coprocessing Distillates

\begin{tabular}{|c|c|c|c|c|}
\hline Coa?, percent & 2 & 20 & 30 & 40 \\
\hline $\begin{array}{l}175-350^{\circ} \mathrm{C} \\
\text { Base Content, } \% \\
\text { Azaarenes } \\
\text { Arylamines* }\end{array}$ & $\begin{array}{l}1.5 \\
0.0563 \\
0.0153\end{array}$ & $\begin{array}{l}2.5 \\
0.0848 \\
0.0395\end{array}$ & $\begin{array}{l}5.3 \\
0.1034 \\
0.0668\end{array}$ & $\begin{array}{l}4.0 \\
0.1144 \\
0.0584\end{array}$ \\
\hline $\begin{array}{l}350-538^{\circ} \mathrm{C} \\
\text { Base Content, } \% \\
\text { Azaarenes } \\
\text { Arylamines* }\end{array}$ & $\begin{array}{l}4.8 \\
0.1195 \\
0.0173\end{array}$ & $\begin{array}{l}5.0 \\
0.1300 \\
0.0250\end{array}$ & $\begin{array}{l}7.2 \\
0.1598 \\
0.0346\end{array}$ & $\begin{array}{l}6.3 \\
0.1676 \\
0.0334\end{array}$ \\
\hline
\end{tabular}

^Meq per gram of distillate 


\section{Distillates Below $175^{\circ} \mathrm{C}$}

Distillates from the 2 and 40 percent coal products boiling below $175^{\circ} \mathrm{C}$ have been analyzed. The procedure, known as the PIANO method, is a capi'lary gas chromatographic method developed for light hydrocarbon analysis. Table 10 shows the results for the two distillate samples. The column labeled Distillate wt \% shows these adjusted to the yields of distillate from tha whole liquid filtrate of the coprocessing products. The cnlum.n labeled Mean M.W. shows the estimated mean molecular weight of each hydrocarbon class.

Table 10

PIANO Analysis of $\angle 175^{\circ} \mathrm{C}$ Distillates

\begin{tabular}{lccc}
\hline & $\begin{array}{c}\text { Distillate, } \\
\text { Wt } \%\end{array}$ & $\begin{array}{c}\text { Filtrate, } \\
\text { Wt } \%\end{array}$ & Mean M.W. \\
\hline 2\% Coal & & & \\
Paraffins & 25.60 & 3.635 & 119.2 \\
Isoparaffins & 31.28 & 4.442 & 128.5 \\
Aromatics & 15.72 & 2.232 & 114.8 \\
Naphthenes & 21.85 & 3.102 & 115.3 \\
Olefins & 4.90 & 0.695 & 116.7 \\
Unknown & 0.66 & 0.093 & - \\
& & & 131.8 \\
40\% Coal & & 1.128 & 139.7 \\
Paraffins & 20.50 & 1.903 & 118.8 \\
Isoparaffins & 34.60 & 1.224 & 126.0 \\
Aromatics & 22.26 & 0.931 & 122.9 \\
Naphthenes & 16.92 & 0.180 & - \\
Olefins & 3.28 & 0.135 & \\
Unknown & 2.45 & & \\
\hline
\end{tabular}

Figures 13 and 14 show the distribution of the major hydrocarbon classes by molecular weight for the two distillates. The most obvious differences are increase of isoparaffins at high molecular weight and of aromatics with increased coal content. All hydrocarbon classes show a shift to higher molecular weight in the 40 percent coal product as shown in both the figures and in Table 10. This corresponds to the amount of condensate obtained in the coprocessing reactions. The 2 percent coal reaction produced 10.29 percent yield of condensate while the 40 percent coal product contained 3.15 percent. condensate. 
Table 11 shows the complete PIANO analysis printout from the 40 percent coal product. This shows the 217 components detected in this particular. sample. This analytical procedure was developed for petroleum products but tt appears to produce good results with ittle unidentified material for the coprocessing products.

\section{Carbon I sotope Ratio Analysis}

Earlier work in this project has shown substantial variation in carbon isotope ratios within the compound class fractions of each coprocessing product. The full list of ratio values for the filtrate, distillate and product residue fraction was shown in Table 4 of the October-December 1989 quarterly report.

A series of analogous fractions prepared from Maya crude in another project study were avallable for comparison. These fractions were prepared directly from the crude ofl without application of hydrogenation or any other processing chemistry. The Maya crude oil fractions and the carbon isotope ratios $\left(\delta^{13} \mathrm{C}\right)$ are shown in Table 12. Values for the 2 and 20 percent coal processing products are shown in Table 13 for comparison.

The shift in $\delta^{13} \mathrm{C}$ values for the distillate fractions of the Maya crude oil clearly correspond to those shown for the coprocessing products. In both cases, the difference between the whole distillate and the acids or bases was somewhat greater for the lower boiling distillate. The magnitude of the differences appears to be comparable for the Maya crude and the coprocessing fractions.

The values for the residue fractions shown in Table 12 are inconsistent with the trends shown in the distillate fractions. The values for these residue fractions may not be very reliable since all of the fractions are more depleted in ${ }^{13} \mathrm{C}$ than the starting residue. This may suggest some contamination (most likely solvent from the separation) of these fractions. Additional separations of Maya $>1000^{\circ} \mathrm{F}$ residue are underway. Isotope ratios for these fractions will be determined to see if this apparent discrepancy can be resolved. 
P. I. A. N. 0 .

The Dotailed Analys ls of Petroleum Hydrocarbon Samples by Capillary Gas Chromatography

Component's Listed in Chromatographic Order

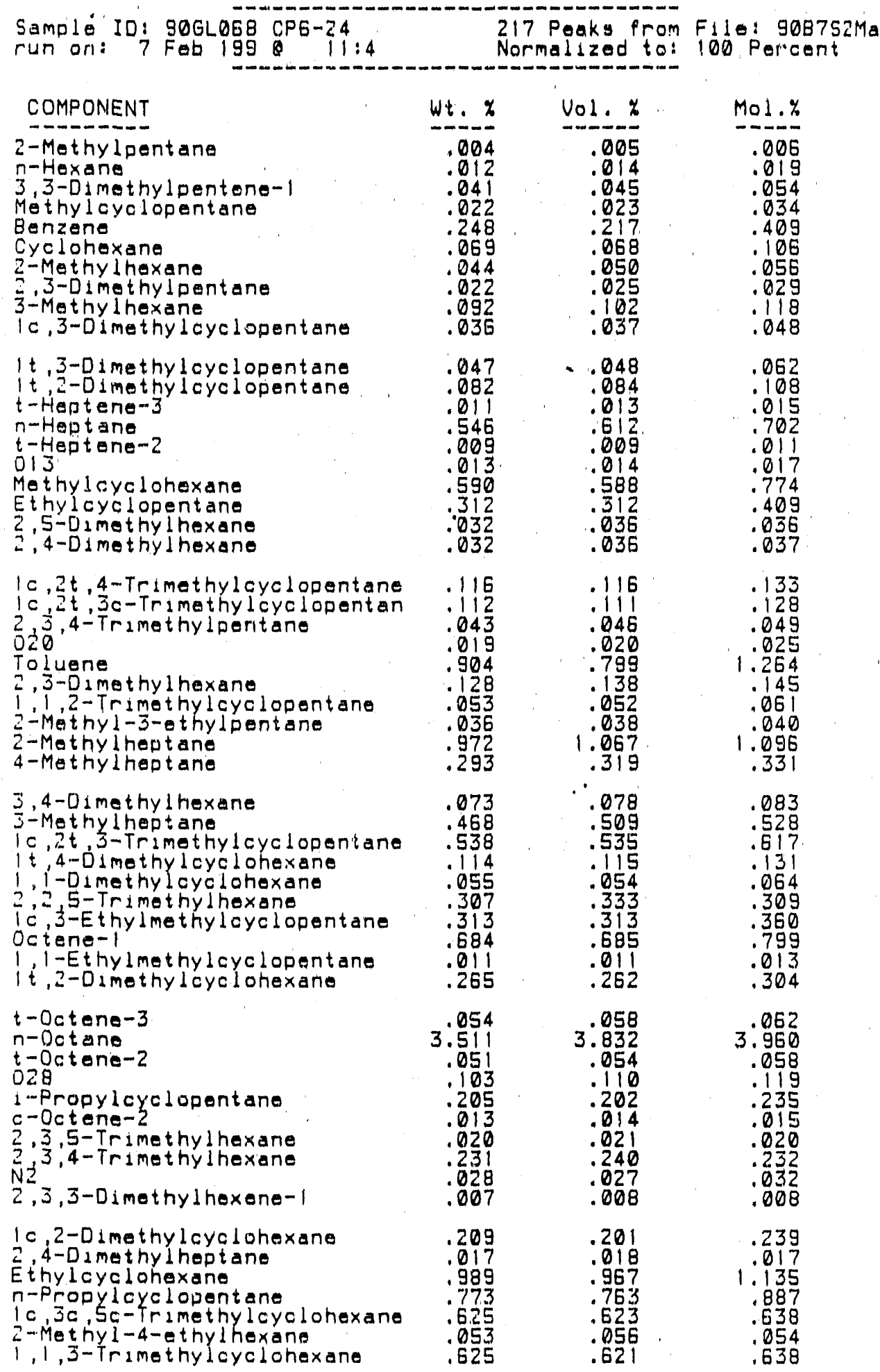


TABLE 11 (contd)

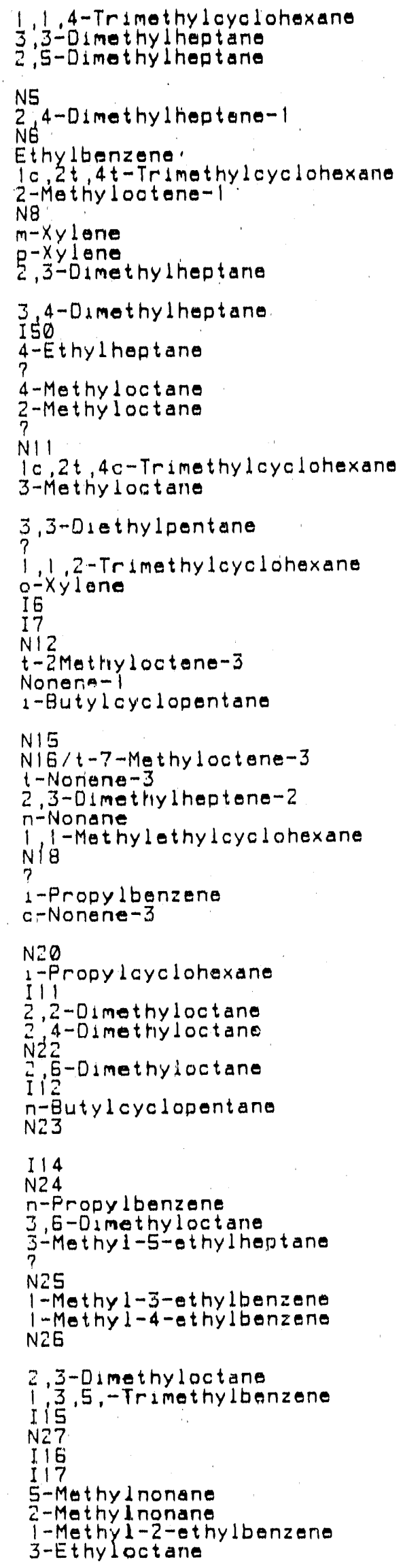

$\begin{array}{rrr}.291 & .289 & .297 \\ .042 & .044 & .042 \\ .156 & .167 & .157 \\ .189 & .186 & .217 \\ .240 & .270 & .253 \\ .087 & .086 & .100 \\ 1.914 & 1.093 & 2.323 \\ .216 & .212 & .220 \\ .165 & .185 & .174 \\ .057 & .056 & .058 \\ 1.705 & 1.516 & 2.073 \\ 1.047 & .933 & 1.271 \\ .031 & .032 & .031\end{array}$

$.344 \quad .351 \quad .346$

.281

.249

.015

.850

1.240

037

.211

.401

1.835

.300

.262

.16

.905

1.332

.040

.208

.388

147
.077

.149

.079

.120

2.016

$-1.756$

.079

.

.356

.983

.373

.293

.965

.420

.420

.288

.228

.111

.196

.242

.773

.010

.251

.239

.225

.109

.205

.272

.735

.295

.010

.223

.282

.251

.015

.854

1.245

- 037

.216

1.843

.552

.288

.330

.275

.053

.245

1.240

.230

.173

536

.147

.078

.128

2.446

.075

1.003

.394

.458

.233

.113

.200

7.356

.788

.310

.010

.243

2.092

.396

.840

.330

.542

.302

2.741

.902

.426

.275

$\therefore 347$

.$\quad 238$

1.638

1.302

.225

.166

. 563

.293

.299

.249

.250

1.407

1.122

.235

2.197

379
747

1.894

.364

.901

$.344 \quad .299$

$.572 \quad .490$

$.319 \quad .274$

2.431

.803

2.938

.967

.392

$.165 \quad .171$

.149

.670

.594

.718

.089

.141

.092

.135

.687

3.711

1.481

. 615

1.307
.583

1.550

1.704

1.138

.080

.130

.622
2.820

1.34

1.462

1.401 
TABLE 11 (contd)

\begin{tabular}{|c|c|c|c|}
\hline 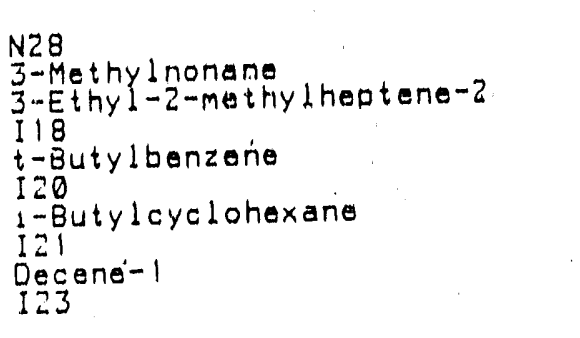 & $\begin{array}{r}.124 \\
1.741 \\
.288 \\
.150 \\
2.263 \\
1.758 \\
.505 \\
.450 \\
.078 \\
.595\end{array}$ & $\begin{array}{r}1119 \\
1.820 \\
.315 \\
2.156 \\
1.023 \\
.486 \\
.466 \\
.081 \\
.616\end{array}$ & $\begin{array}{r}1114 \\
1.576 \\
.273 \\
2.136 \\
1.172 \\
1.592 \\
.484 \\
.408 \\
.072 \\
.539\end{array}$ \\
\hline 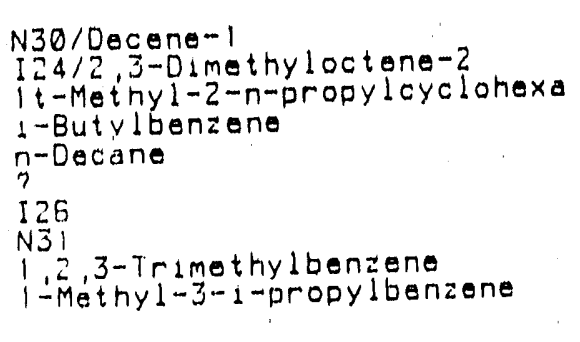 & $\begin{array}{r}183 \\
.224 \\
.260 \\
7212 \\
7.979 \\
.099 \\
.242 \\
.264 \\
.828 \\
.330\end{array}$ & $\begin{array}{r}.176 \\
.232 \\
.249 \\
.191 \\
8.380 \\
.103 \\
.251 \\
.253 \\
.710 \\
.293\end{array}$ & $\begin{array}{r}.169 \\
.203 \\
.239 \\
.204 \\
7.224 \\
.089 \\
.199 \\
.220 \\
.887 \\
.316\end{array}$ \\
\hline 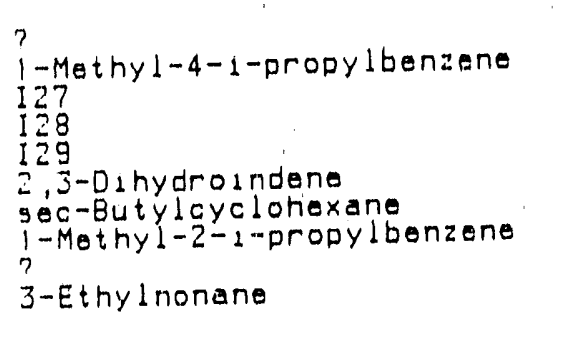 & $\begin{array}{r}.243 \\
.247 \\
.107 \\
.106 \\
1.138 \\
1.173 \\
1.361 \\
.090 \\
.289 \\
.498\end{array}$ & $\begin{array}{r}.216 \\
.220 \\
.111 \\
1.110 \\
1.179 \\
1.237 \\
.272 \\
.253 \\
.513\end{array}$ & $\begin{array}{r}.233 \\
.237 \\
.088 \\
.087 \\
.938 \\
.188 \\
1.258 \\
.087 \\
.277 \\
.411\end{array}$ \\
\hline 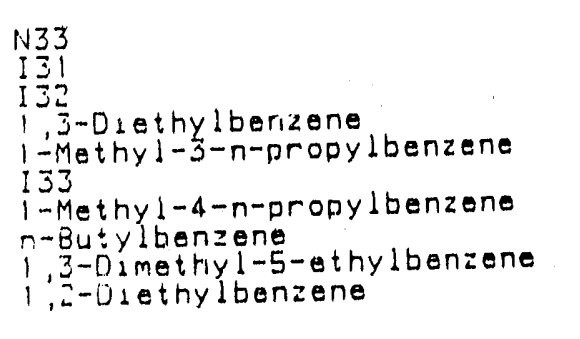 & $\begin{array}{r}.958 \\
.692 \\
.207 \\
.389 \\
.681 \\
.107 \\
.321 \\
.142 \\
.307 \\
.127\end{array}$ & $\begin{array}{l}.918 \\
.717 \\
.198 \\
.345 \\
.606 \\
.111 \\
.286 \\
.127 \\
.268 \\
.111\end{array}$ & $\begin{array}{l}.800 \\
.570 \\
.173 \\
.374 \\
.653 \\
.088 \\
.308 \\
.136 \\
.295 \\
.122\end{array}$ \\
\hline $\begin{array}{l}? \\
134 \\
1-11 \text { ethy } 1-2-n \text {-propy lbenzene } \\
135 \\
137 \\
138 \\
1,4-01 \text { methyl-2-ethylbenzene } \\
1,3-0 \text { imethyl-4-ethylbenzene } \\
\text { I } 39\end{array}$ & $\begin{array}{l}.744 \\
.892 \\
.191 \\
.370 \\
.373 \\
.523 \\
.213 \\
.182 \\
.075 \\
.342\end{array}$ & $\begin{array}{r}.649 \\
.924 \\
.168 \\
.384 \\
.387 \\
.542 \\
.186 \\
.162 \\
.067 \\
.354\end{array}$ & $\begin{array}{l}.714 \\
.735 \\
.183 \\
.305 \\
.208 \\
.431 \\
.204 \\
.158 \\
.065 \\
.282\end{array}$ \\
\hline $\begin{array}{l}1,2-D 1 \text { methyl-4-ethylbenzene } \\
\text { I } 40 \\
1,3-01 \text { methyl-z-ethylbenzene } \\
141 \\
142 \\
? \\
1 \text { - Methyl-4-t-butylbenzene } \\
1,2-0 \text { dmethyl-j-ethylbenzene }\end{array}$ & $\begin{array}{l}.441 \\
.083 \\
.047 \\
.076 \\
.108 \\
.200 \\
.095 \\
.064 \\
.127 \\
.067\end{array}$ & $\begin{array}{l}.387 \\
.073 \\
.048 \\
.065 \\
.112 \\
.207 \\
.098 \\
.067 \\
.115 \\
.057\end{array}$ & $\begin{array}{l}.423 \\
.080 \\
.038 \\
.073 \\
.089 \\
.165 \\
.078 \\
.053 \\
.111 \\
.064\end{array}$ \\
\hline 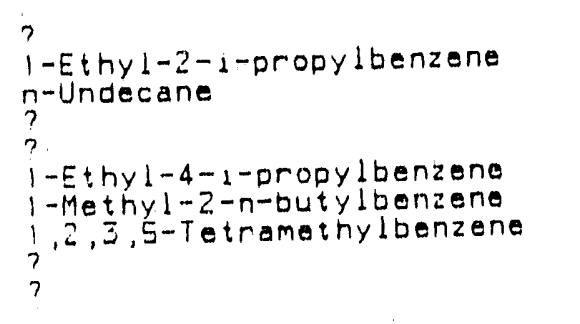 & $\begin{array}{r}.007 \\
.028 \\
1.074 \\
.052 \\
.008 \\
.015 \\
.020 \\
.019 \\
.048 \\
.038\end{array}$ & $\begin{array}{r}.006 \\
.024 \\
1.107 \\
.053 \\
.009 \\
.013 \\
.017 \\
.016 \\
.042 \\
.033\end{array}$ & $\begin{array}{l}.007 \\
.024 \\
.885 \\
.043 \\
.007 \\
.013 \\
.017 \\
.018 \\
.046 \\
.037\end{array}$ \\
\hline 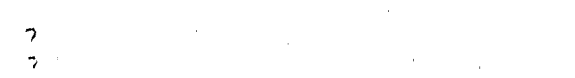 & $\begin{array}{l}.029 \\
.021\end{array}$ & $\begin{array}{r}.025 \\
.018\end{array}$ & $\begin{array}{l}.028 \\
.020\end{array}$ \\
\hline
\end{tabular}


TABLE 11 (contd)

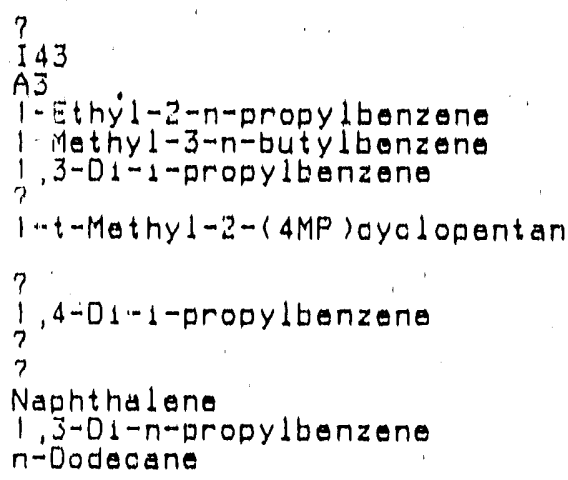

$\begin{array}{ll}.024 & .021 \\ .103 & .105 \\ .011 & .009 \\ .037 & .032 \\ .081 & .070 \\ .035 & .030 \\ .031 & .027 \\ .022 & .021 \\ .024 & .023 \\ .015 & .013 \\ .012 & .011 \\ .019 & .015 \\ .027 & .020 \\ .013 & .011 \\ .038 & .039\end{array}$

.818

.012

.010

.015

.027

.011 
TAESLE 12

Maya Crude Fractions and Carbon Isotope Rattos

\begin{tabular}{|c|c|}
\hline Fraction & $\delta^{13} \mathrm{C}$ \\
\hline 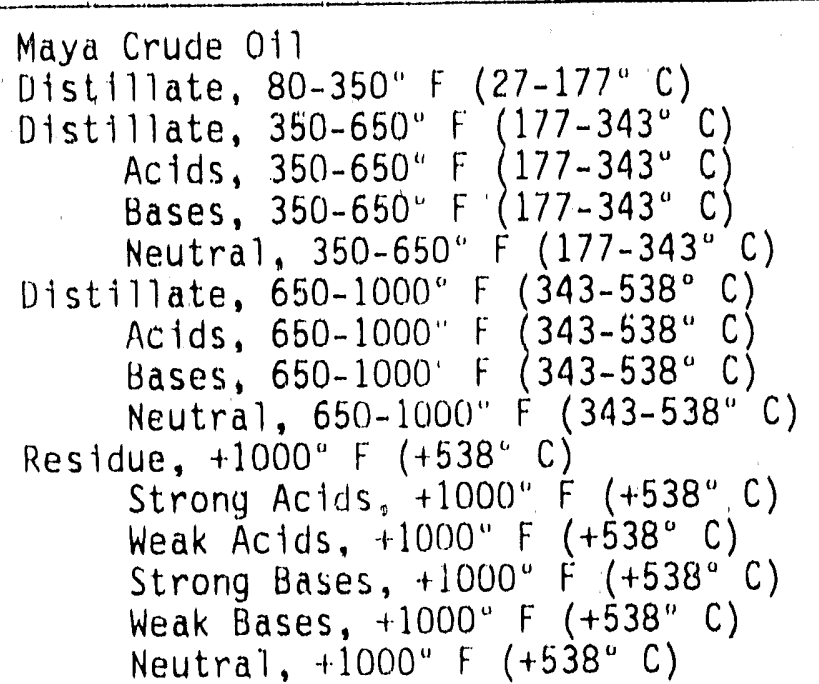 & $\begin{array}{l}-27.67 \\
-27.72 \\
-27.77 \\
-26.14 \\
-25.73 \\
-27.79 \\
-27.71 \\
-26.58 \\
-26.36 \\
-27.75 \\
-27.60 \\
(\text { to be repeated) } \\
-28.07 \\
-27.97 \\
-27.95 \\
-27.97\end{array}$ \\
\hline
\end{tabular}

TABLE 13

Isotope Ratio Values for Coprocessing Fractions, $\delta^{13} \mathrm{C}$

\begin{tabular}{|c|c|c|}
\hline Coal, \% & 2 & 20 \\
\hline $\begin{array}{l}\text { Filtrate } \\
\text { Distillate, to } 175^{\circ} \mathrm{C} \\
175-350^{\circ C} \mathrm{C} \text { fractions } \\
\text { Whole distillate } \\
\text { Actds } \\
\text { Bases } \\
\text { Neutral } \\
\text { 350-538 C fractions } \\
\text { Whole distillate } \\
\text { Actds } \\
\text { Bases } \\
\text { Neutral } \\
\text { Restdue }>538^{\circ} \mathrm{C}\end{array}$ & $\begin{array}{l}-26.38 \\
-25.88 \\
-24.80 \\
-26.41 \\
-26.24 \\
-25.64 \\
-25.42 \\
-26.43 \\
-26.94\end{array}$ & $\begin{array}{l}-26.45 \\
-24.51 \\
-24.19 \\
-26.68 \\
-26.05 \\
-25.54 \\
-24.77 \\
-26.34 \\
-26.14\end{array}$ \\
\hline
\end{tabular}


In comparing the residue values, tt should be remembered that the coprocessing products were prepared from the Maya $>1000$ " $F$ residue. If the lack of tsotoplc shlft shown for the Maya crude restdue fractions in Table 12 is valld, the tsotoptc shift determined for the coprocessing products should be the result of processing reactions that are sensitive to tsotope reactivity. However, if the shift shown for the distillate fractions correctly represents the compound classes throughout the Maya cruile, the shifts shown for the coprocessing fractions are directly received from the parent compound classes and are not the result of processing reactions. The latter explanation appears more probable. 

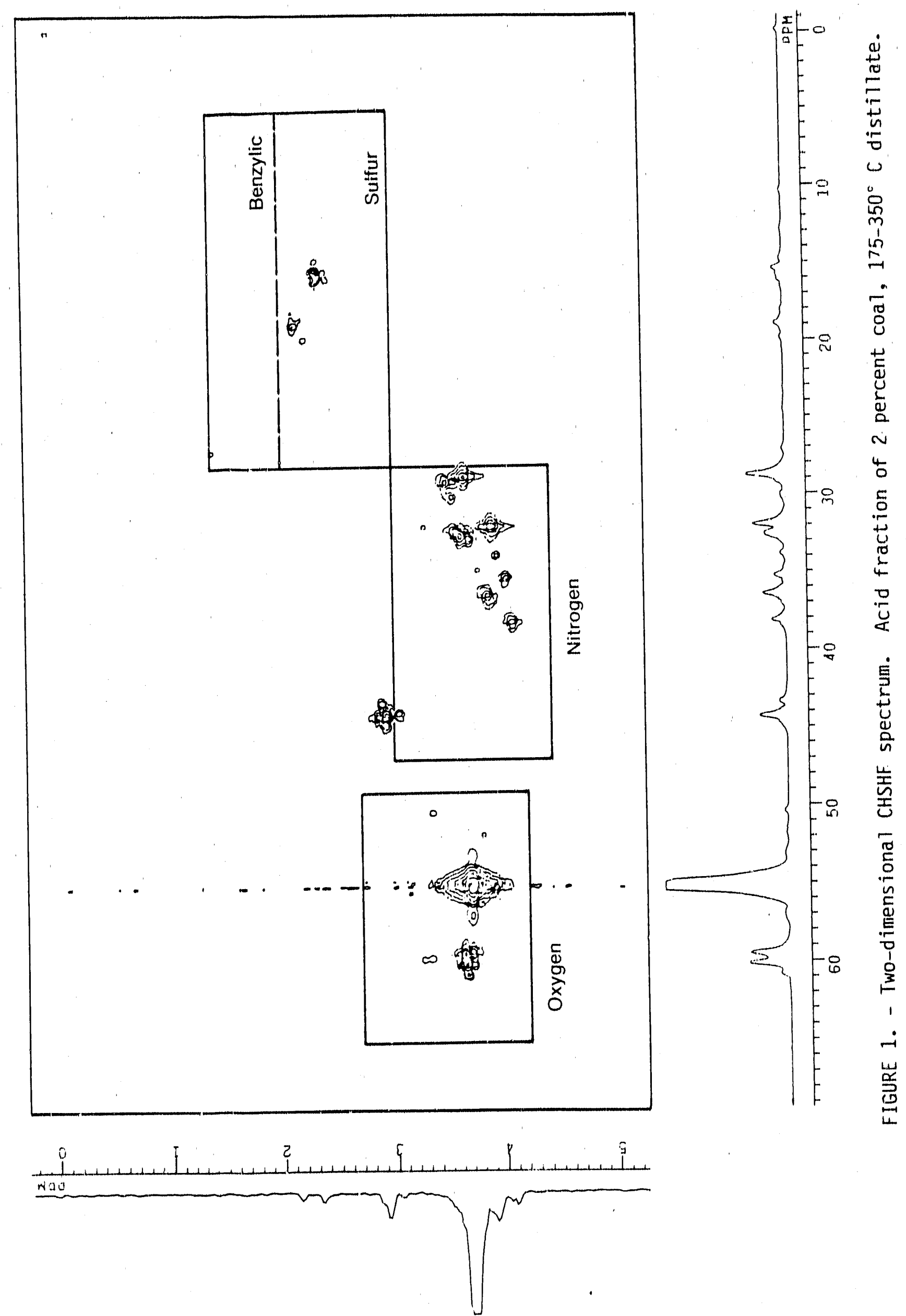


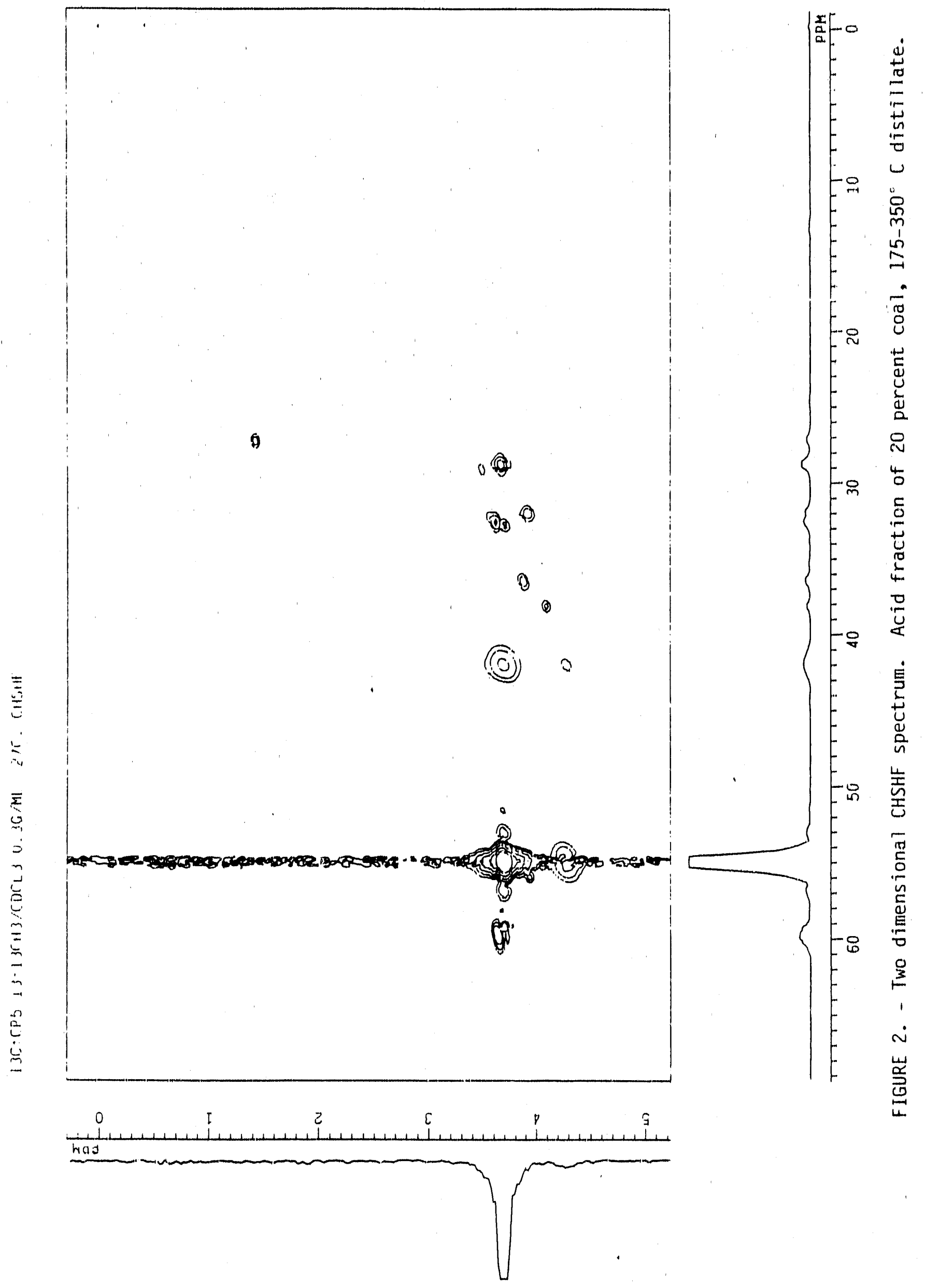




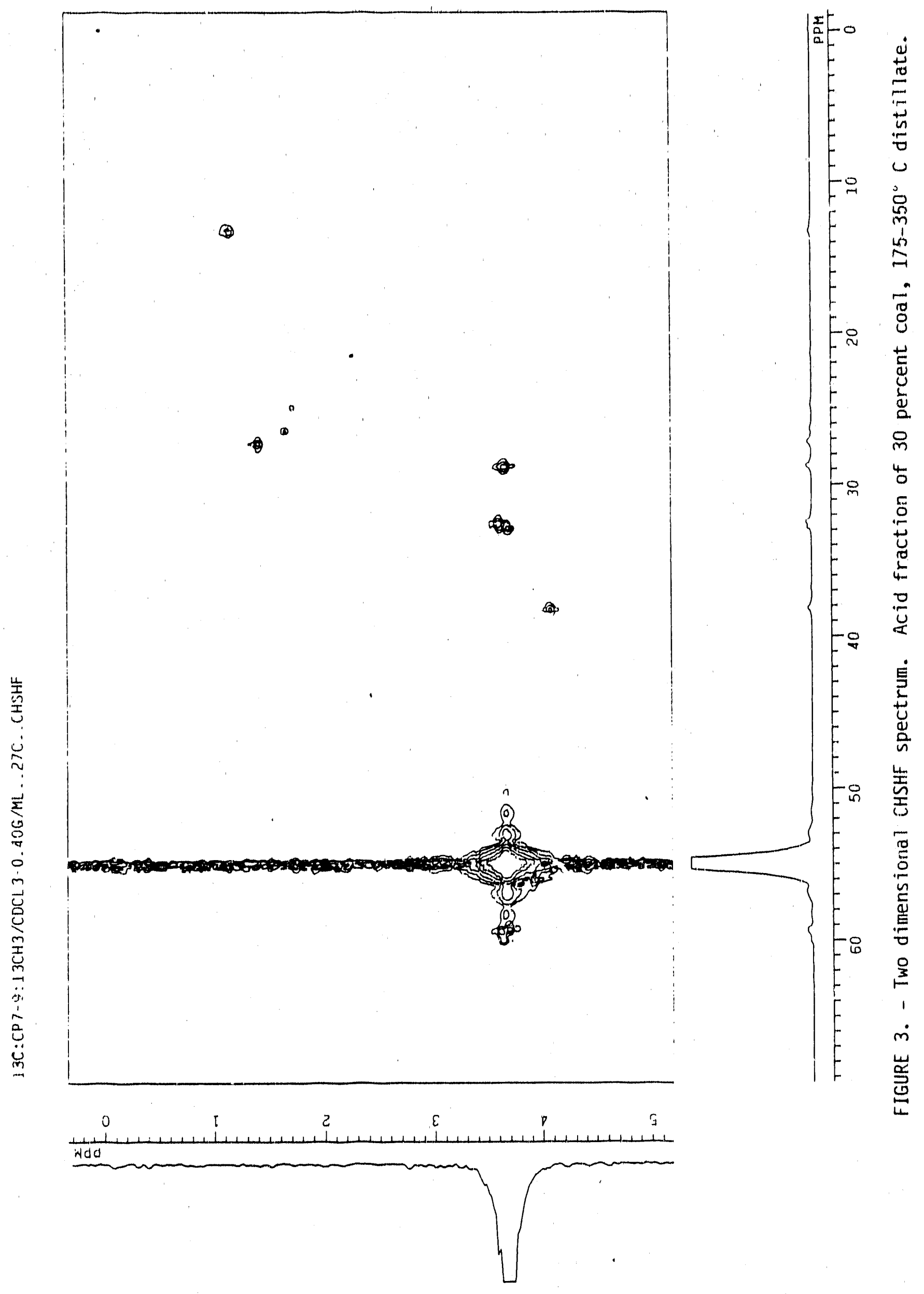




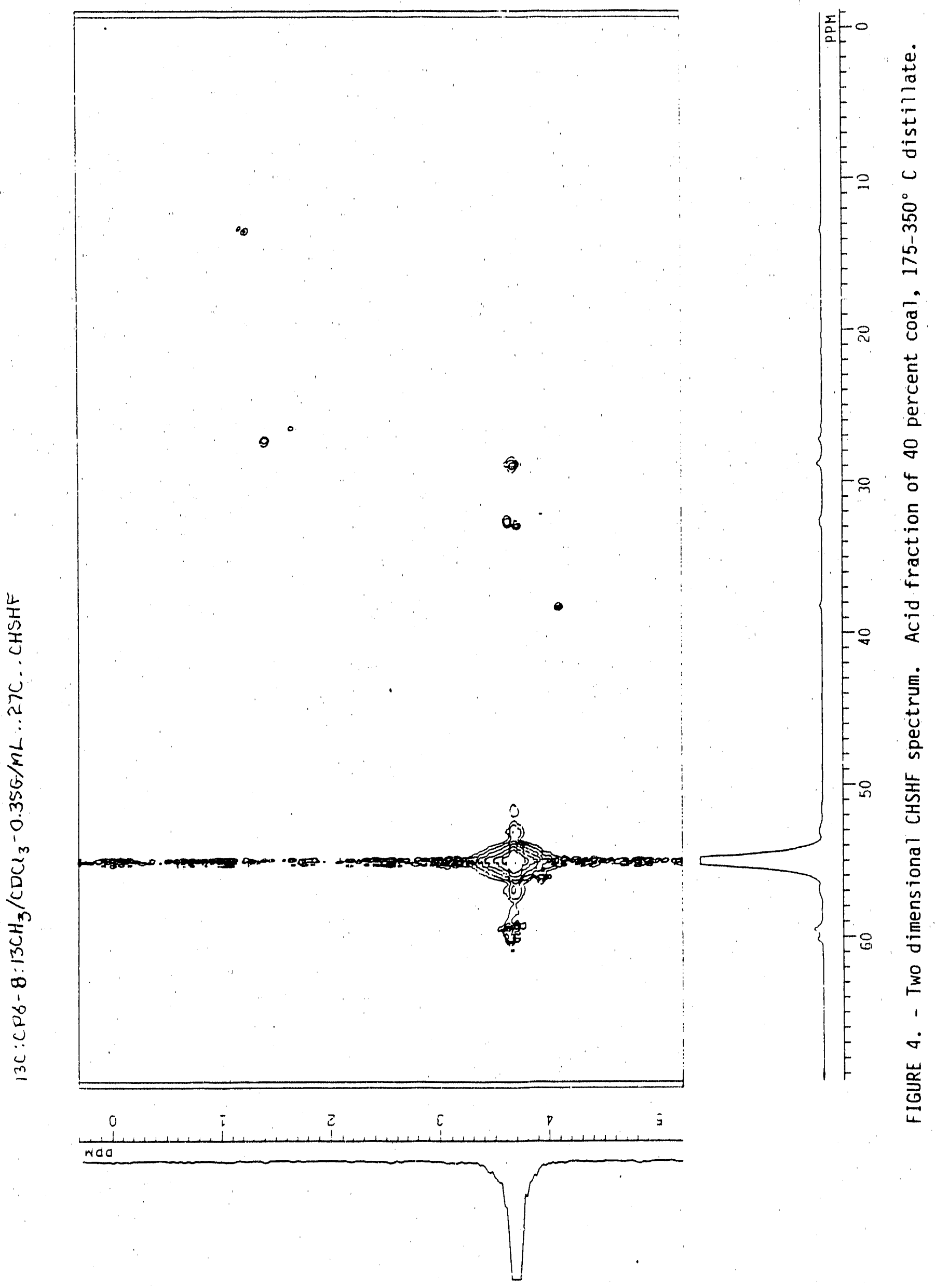




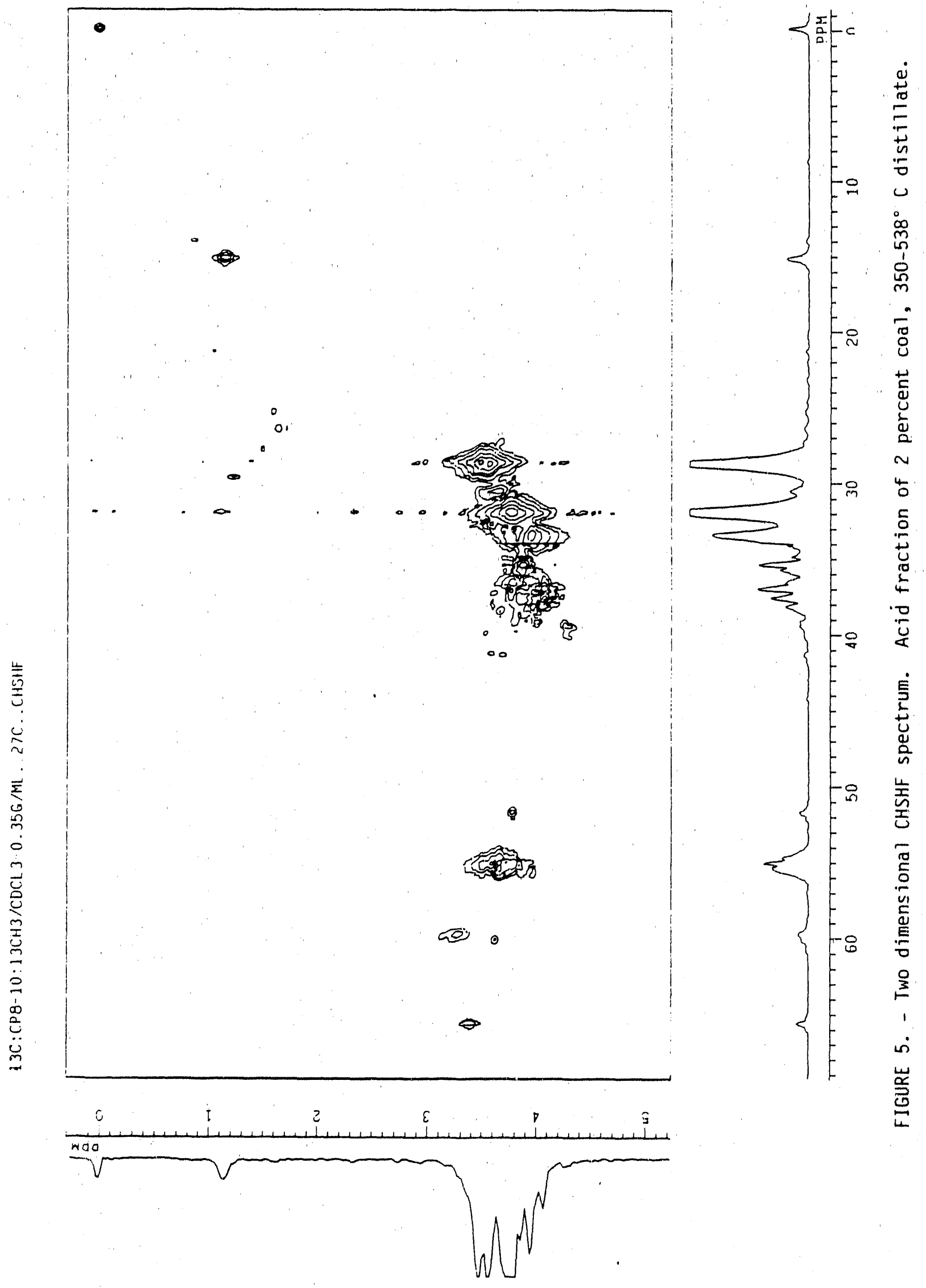




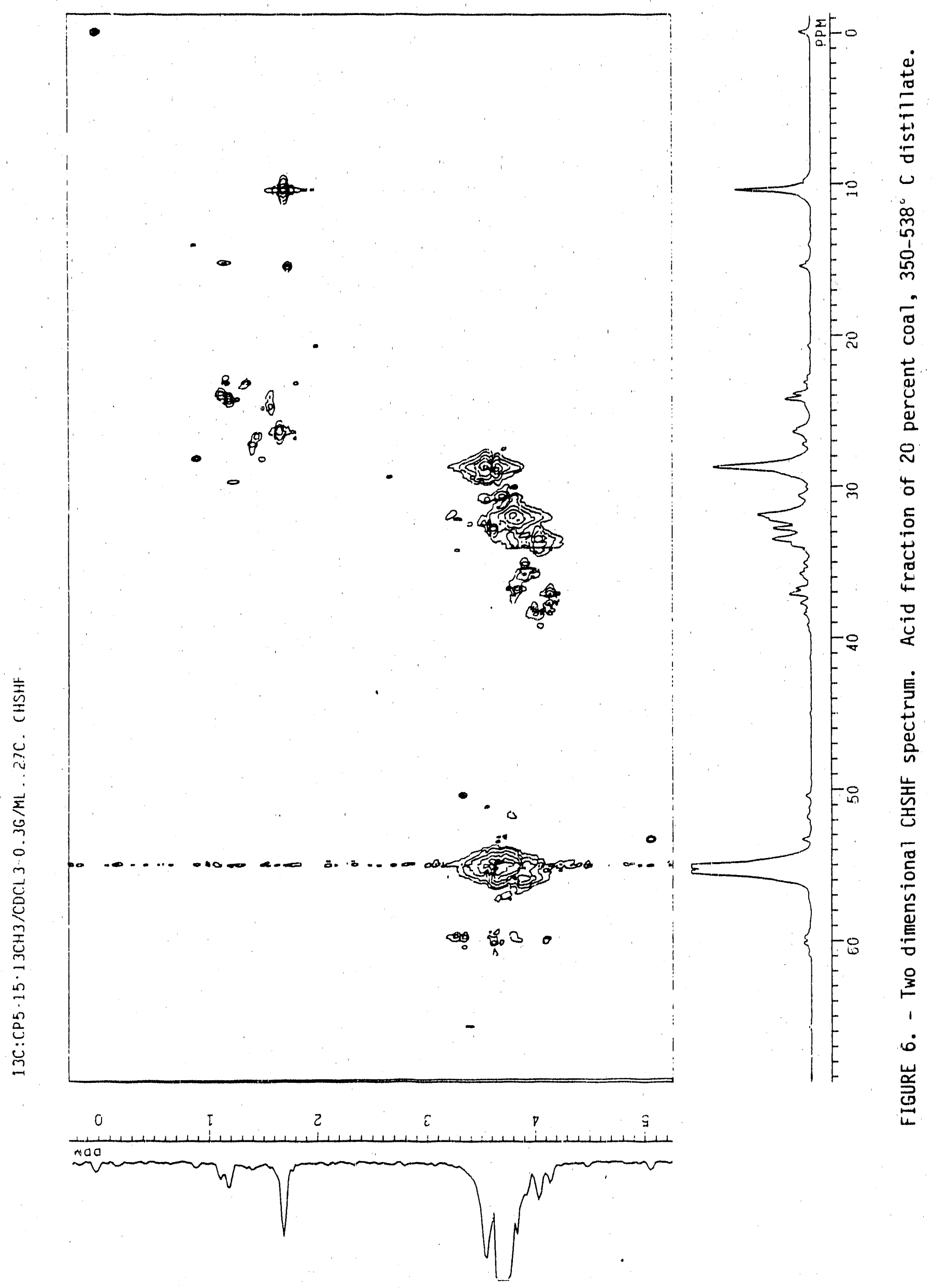




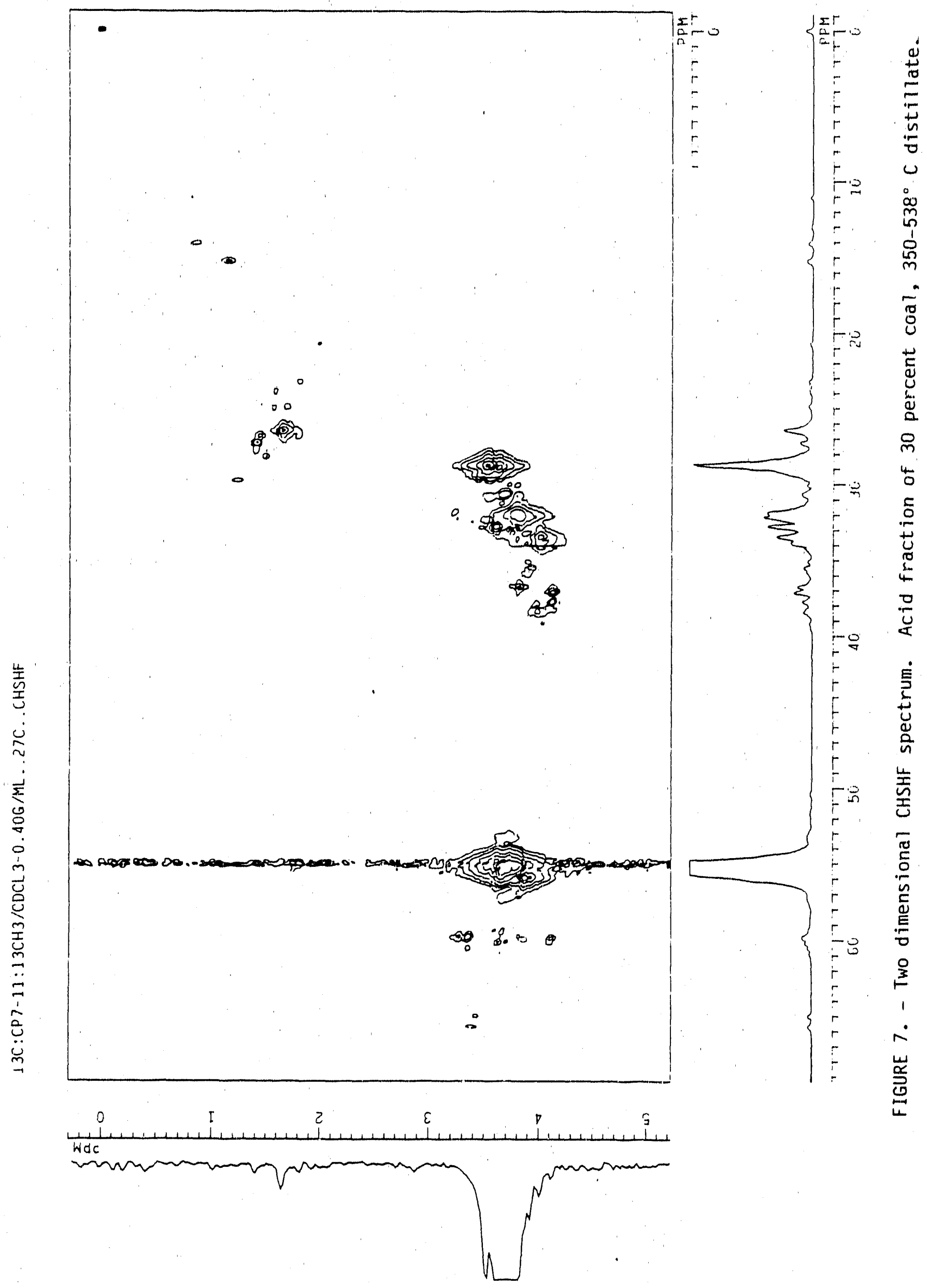



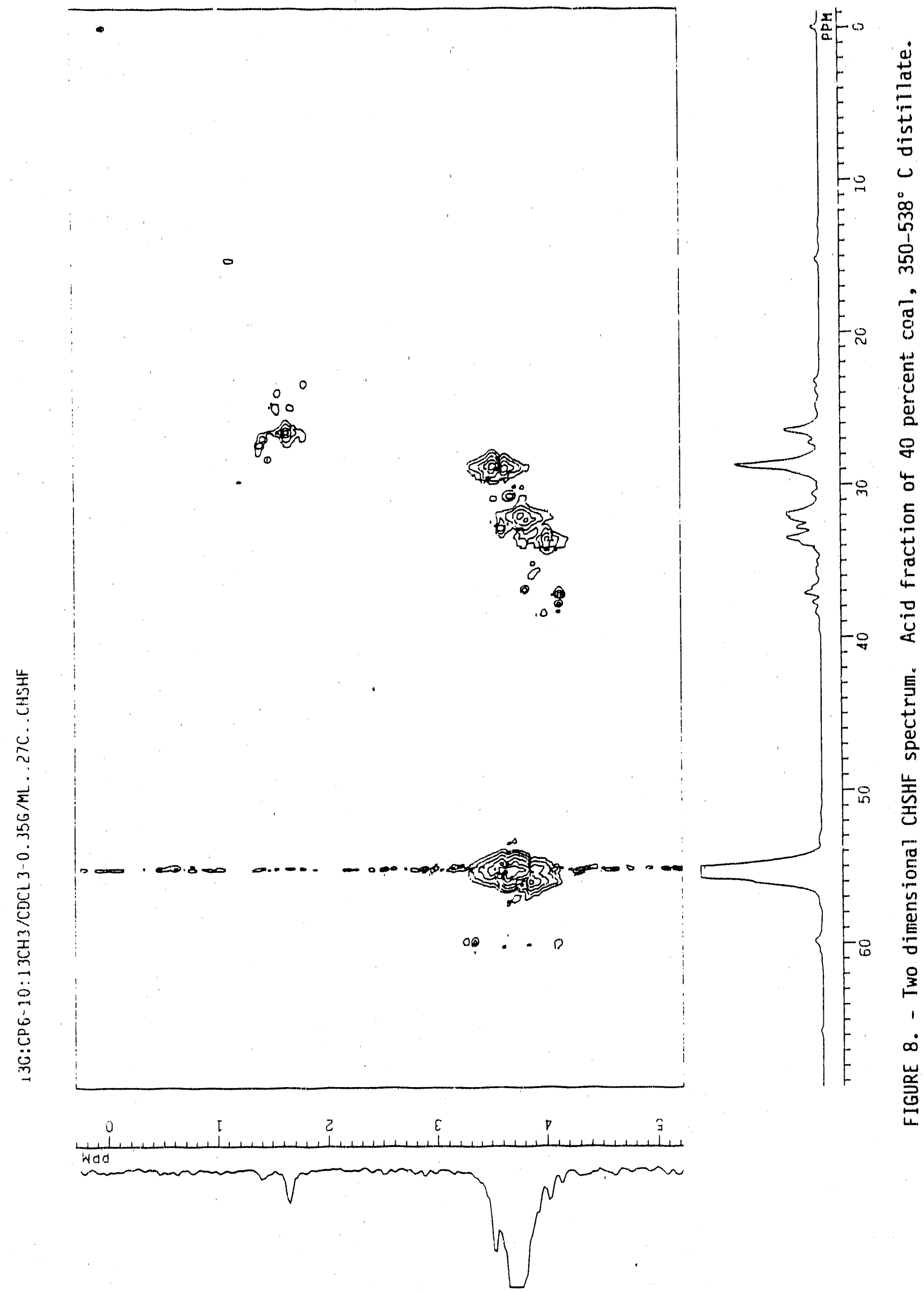


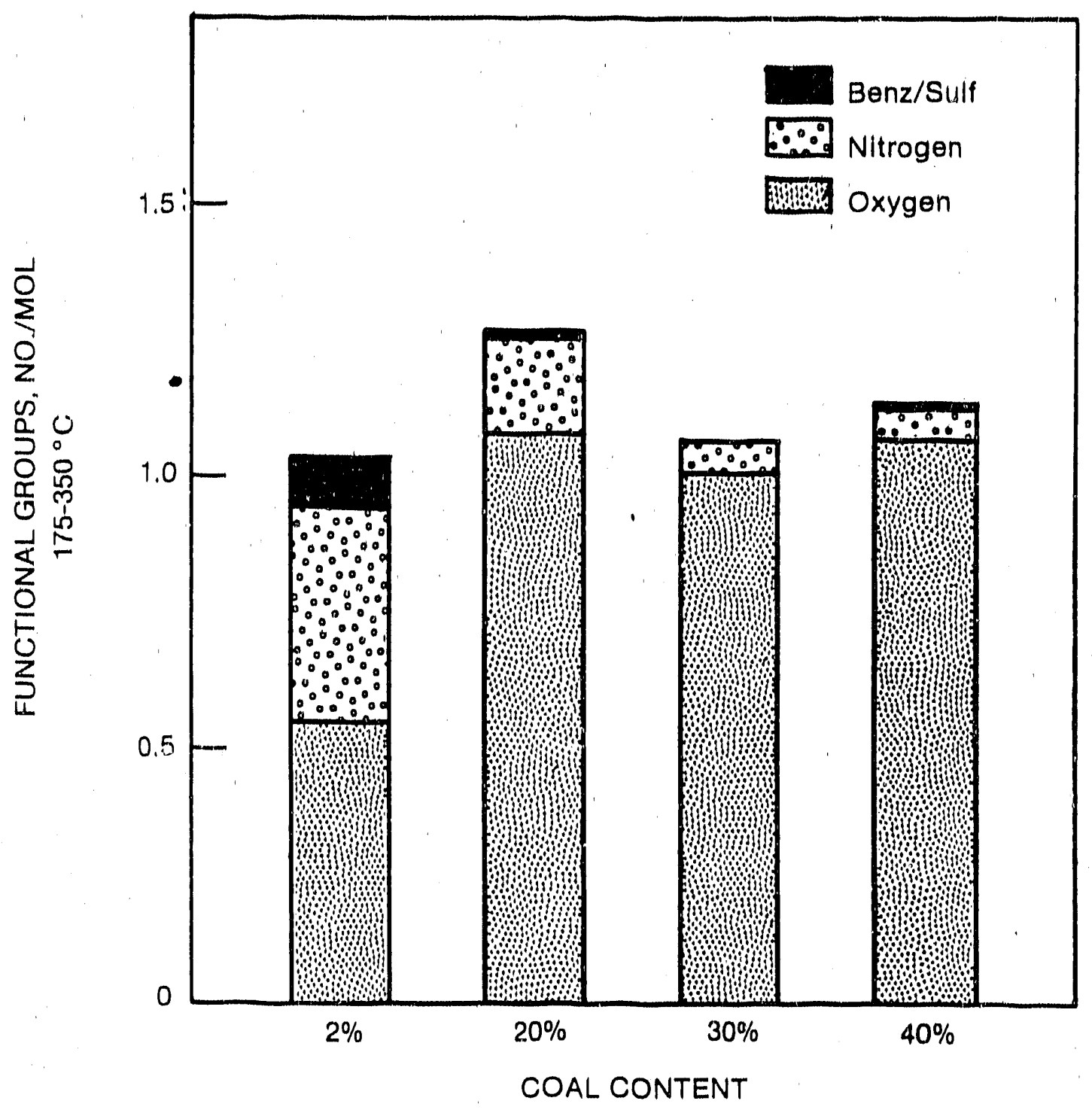

FIGURE 9. - Number of functional groups per molecule for the 175-350 $\mathrm{C}$ products. 


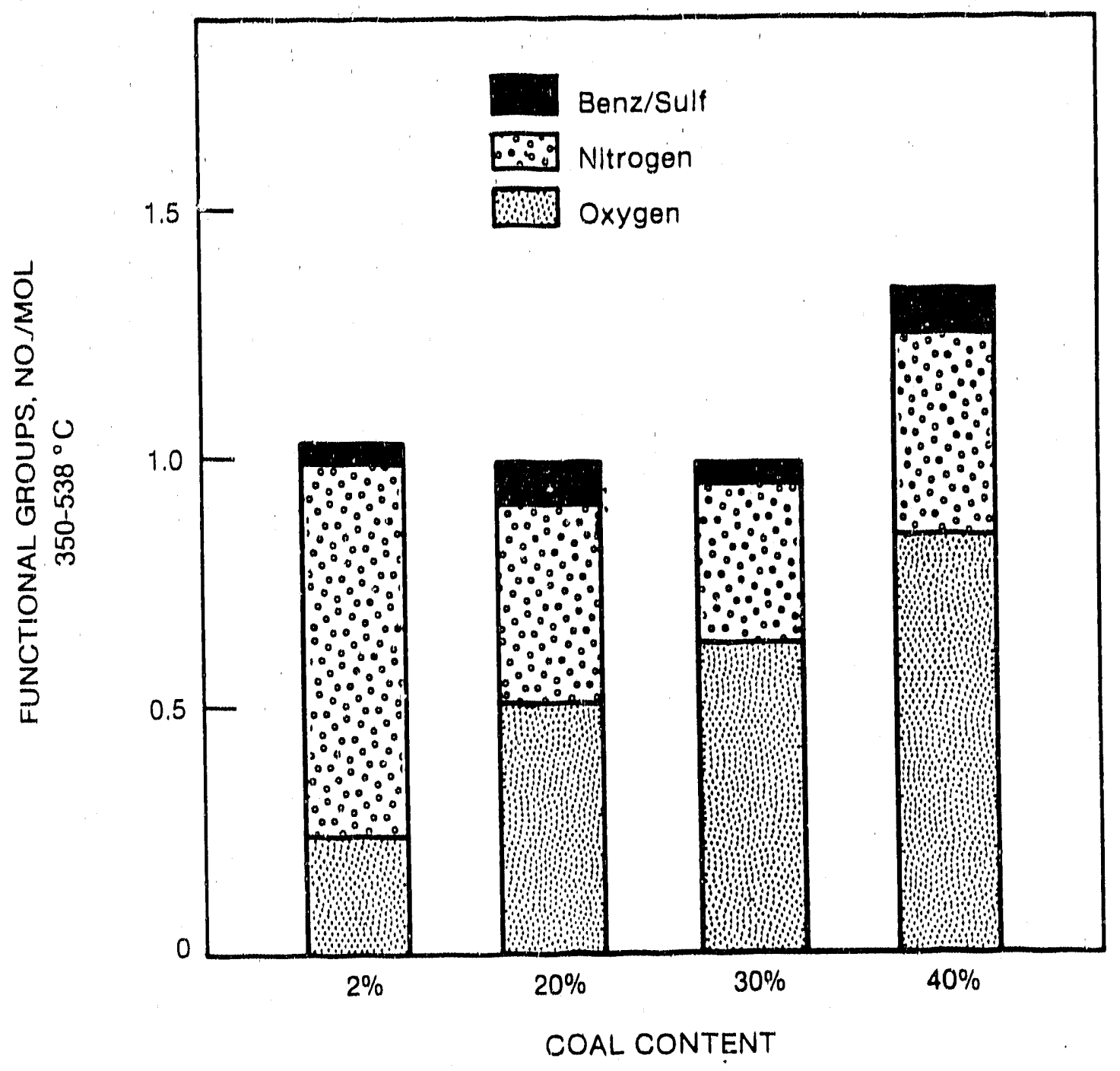

FIGURE 10. - Number of functional groups per molecule for the 350-538 C products. 


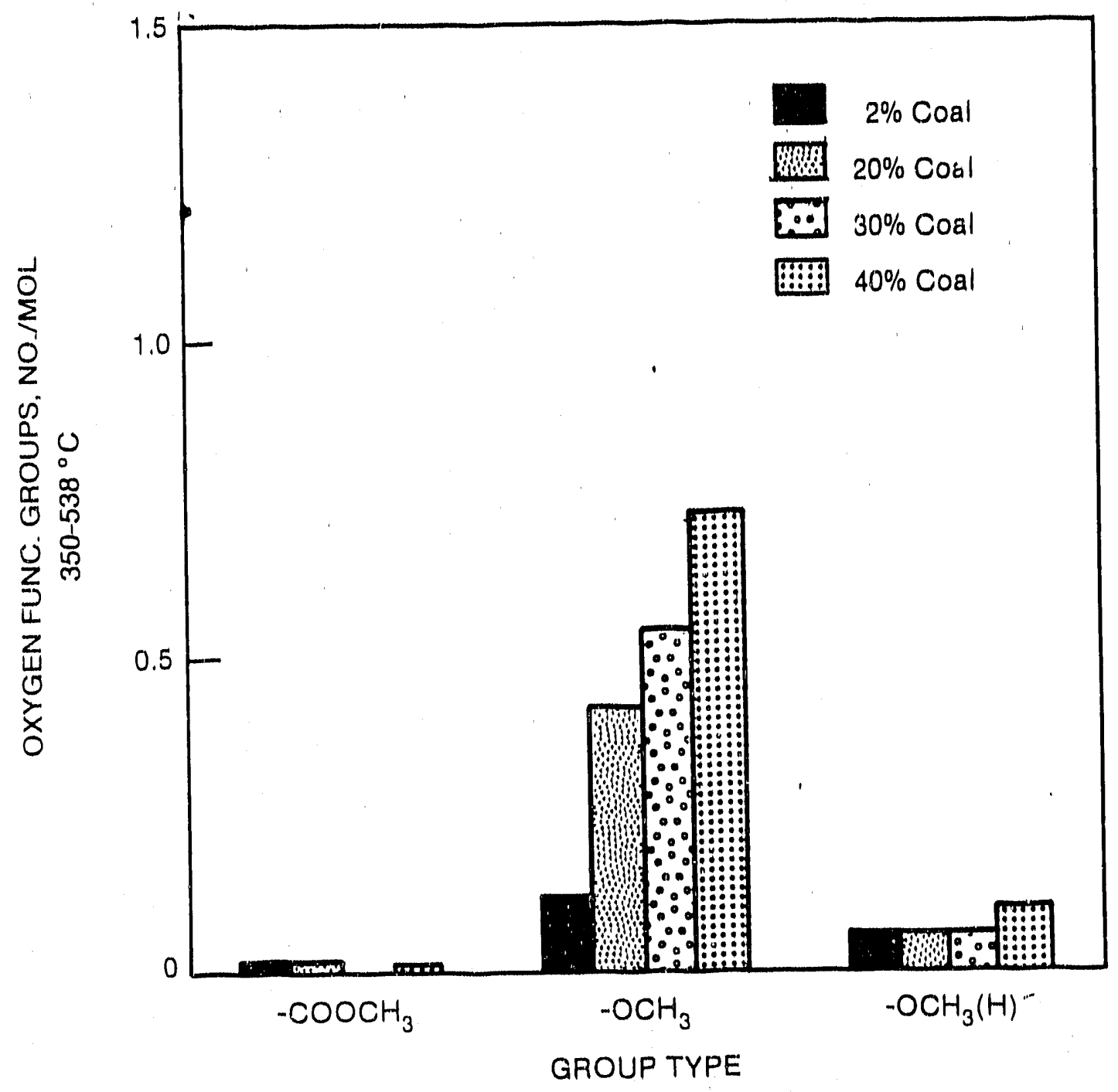

FIGURE 11. - Distribution of oxygen functional groups in the $175-350^{\circ} \mathrm{C}$ products. 


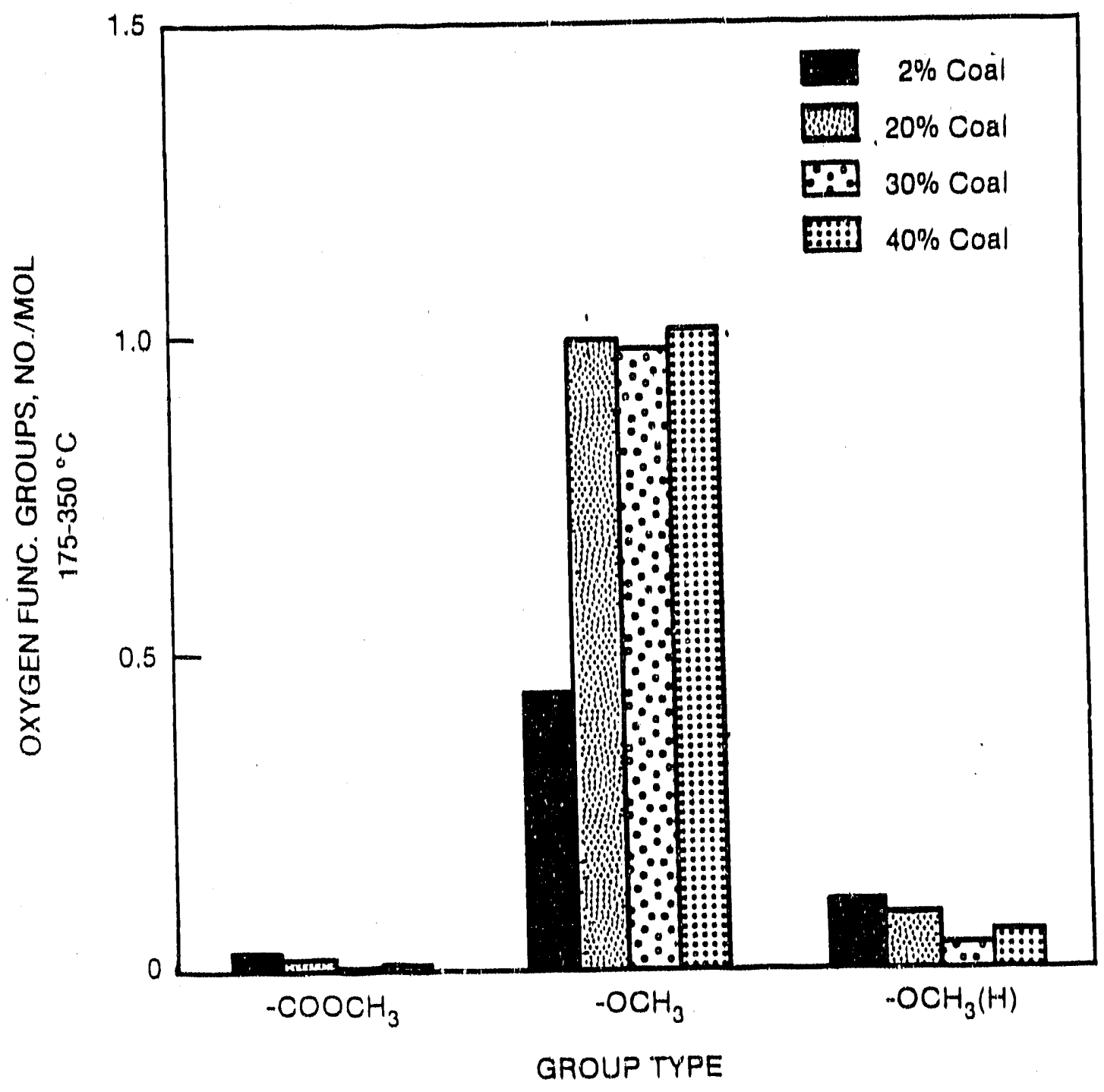

FIGURE 12. - Distribution of oxygen functional groups in the $350-538^{\circ} \mathrm{C}$ products. 


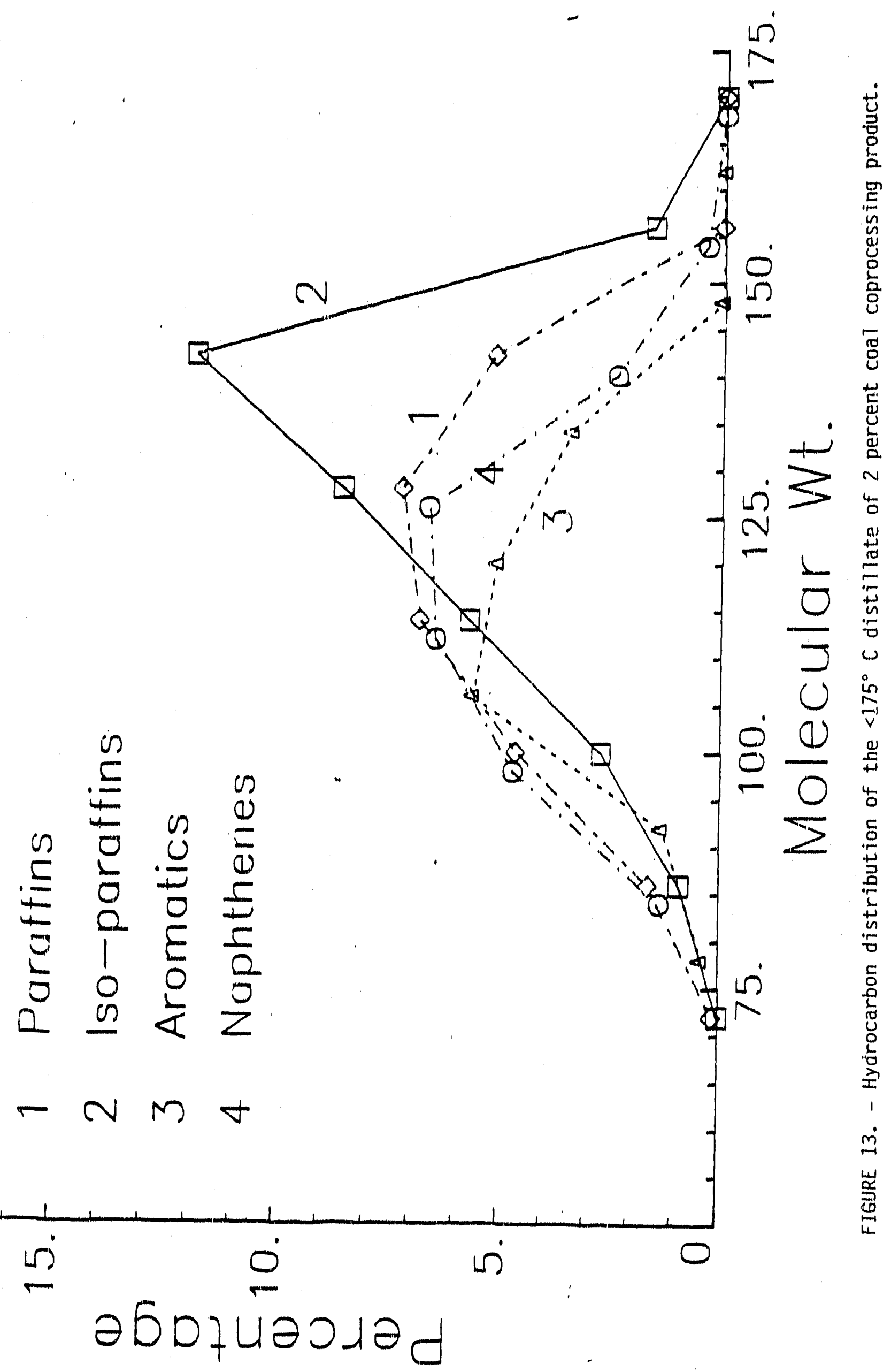




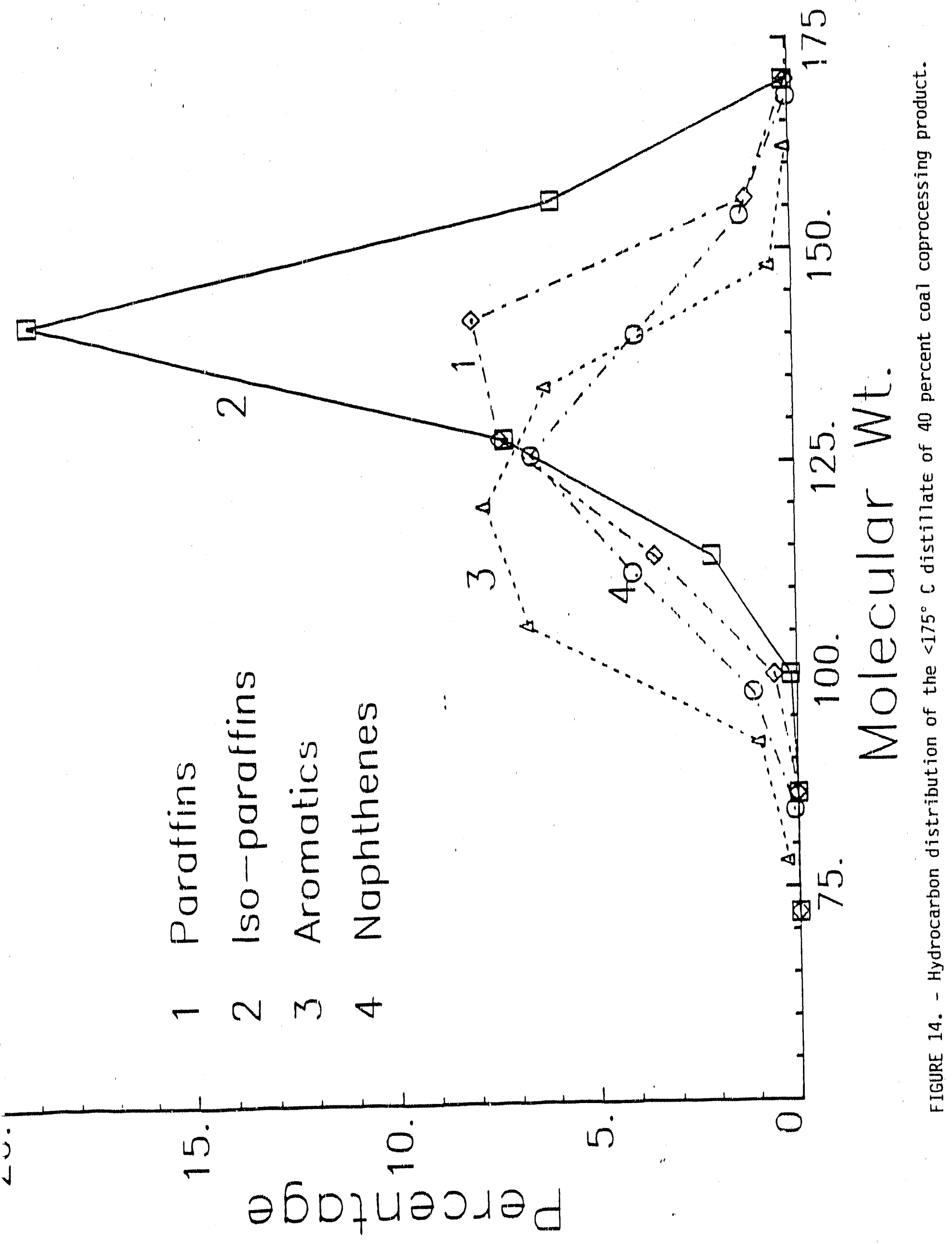



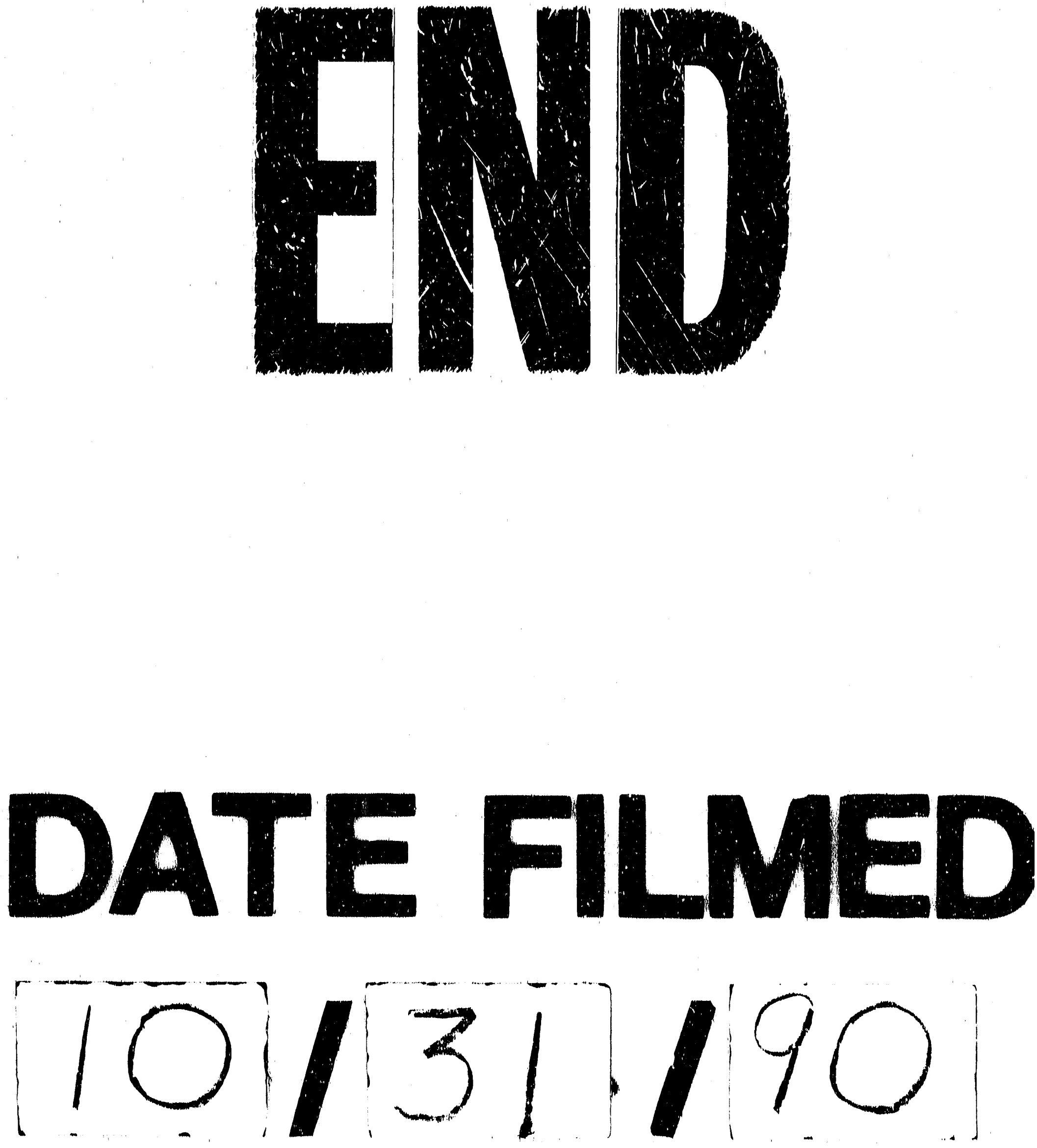
